\title{
Osmium-Promoted Transformation of Alkyl Nitriles to Secondary Aliphatic Amines: Scope and Mechanism
}

\author{
Juan C. Babón, Miguel A. Esteruelas, * Ana M. López, and Enrique Oñate \\ Cite This: https://dx.doi.org/10.1021/acs.organomet.0c00236 \\ Read Online
}

ABSTRACT: The transformation of alkyl nitriles to symmetrical and asymmetrical secondary aliphatic amines promoted by the hexahydride complex $\mathrm{OsH}_{6}\left(\mathrm{P}^{\mathrm{i}} \mathrm{Pr}_{3}\right)_{2}(\mathbf{1})$ is described, and the mechanisms of the reactions involved are established. Complex 1 catalyzes the aforementioned transformations of aryl-, pyridyl-, and alkoxy-functionalized alkyl nitriles with linear or branched chains. The formation of the secondary amines involves primary imines, primary amines, and secondary imines as organic intermediates. The reactions take place under mild conditions (toluene, $100{ }^{\circ} \mathrm{C}$, and 4 bar of $\mathrm{H}_{2}$ ). Stoichiometric reactions of 1 with pivalonitrile and 2-methoxyacetonitrile have allowed us to isolate the trihydride azavinylidene

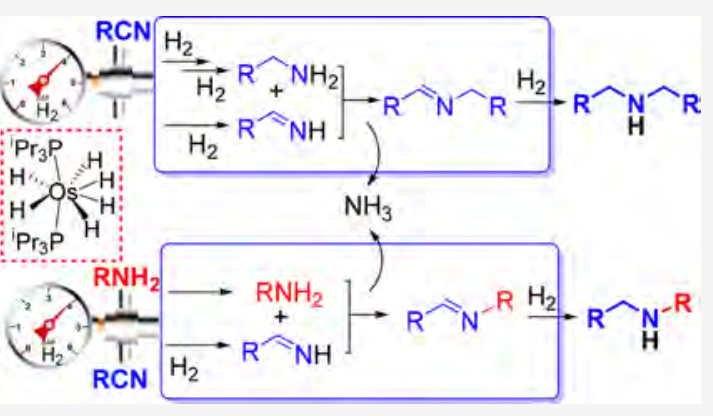
derivatives $\mathrm{OsH}_{3}\{=\mathrm{N}=\mathrm{CHR}\}\left(\mathrm{P}^{\mathrm{i}} \mathrm{Pr}_{3}\right)_{2}\left(\mathrm{R}={ }^{\mathrm{t}} \mathrm{Bu}(3), \mathrm{CH}_{2} \mathrm{OMe}(4)\right)$. Their formation involves the insertion of the $\mathrm{N}-\mathrm{C}$ triple bond of the substrates into an $\mathrm{Os}-\mathrm{H}$ bond of the unsaturated tetrahydride $\mathrm{OsH}_{4}\left(\mathrm{P}^{\mathrm{i}} \mathrm{Pr}_{3}\right)_{2}$ (A), which is generated by reductive elimination of $\mathrm{H}_{2}$ from the hexahydride precursor. The reaction of these trihydride azavinylidene species with $\mathrm{H}_{2}$ is the key step for the reduction of the $\mathrm{N}-\mathrm{C}$ triple bond of the nitriles. In the absence of $\mathrm{H}_{2}$, the attack of $\mathbf{A}$ to the azavinylidene ligand produces the rupture of its $\mathrm{C}\left(\mathrm{sp}^{2}\right)-\mathrm{C}\left(\mathrm{sp}^{3}\right)$ bond. As a consequence of this attack and the presence of primary imines and amines in the reaction media, the binuclear complexes $\left(\mathrm{P}^{\mathrm{i}} \operatorname{Pr}_{3}\right)_{2} \mathrm{H}_{4} \mathrm{Os}(\mu-\mathrm{CN}) \mathrm{OsH} 3 \kappa^{1}-N-(\mathrm{NH}=$ $\left.\left.\mathrm{CHCH}_{2} \mathrm{OMe}\right)\right\}\left(\mathrm{P}^{\mathrm{i}} \mathrm{Pr}_{3}\right)_{2}$ (5) and $\left(\mathrm{P}^{\mathrm{i}} \mathrm{Pr}_{3}\right)_{2} \mathrm{H}_{4} \mathrm{Os}(\mu-\mathrm{CN}) \mathrm{OsH}_{3}\left\{\kappa^{1}-\mathrm{N}-\left(\mathrm{NH}_{2} \mathrm{CH}_{2} \mathrm{CH}_{2} \mathrm{OMe}\right)\right\}\left(\mathrm{P}^{\mathrm{i}} \operatorname{Pr}_{3}\right)_{2}$ (6) have been isolated and characterized by X-ray diffraction analysis, for 2-methoxyacetonitrile. DFT calculations reveal noticeable similarities between the hydrogenations of nitriles to primary imines and those of primary imines to primary amines.

\section{INTRODUCTION}

Aliphatic amines are some of the most relevant organic molecules. The alkyl groups appended to the nitrogen atom control the physical properties of the compounds, which are important for regulating key biological interactions. Thus, aliphatic amines are common among pharmaceutical agents, small-molecule biological probes, and preclinical candidates. ${ }^{1}$ Traditional procedures for their production involve the $\mathrm{N}$ alkylation of amines and carbonyl reductive amination. ${ }^{2}$ The reaction between simple amines and alkyl halides enables the construction of higher order amines. However, despite the great efforts that have been carried out, there is not a general procedure that guarantees high selectivity. ${ }^{3}$ Carbonyl reductive amination is the most widely employed alternative to the $\mathrm{N}$ alkylation, but its use generates too many environmental problems. ${ }^{3,4}$ As a consequence of these issues, new strategies based on transition-metal catalysis are being developed, including hydroamination, hydroaminoalkylation, $\mathrm{C}\left(\mathrm{sp}^{3}\right)-\mathrm{H}$ functionalization, and visible light photoredox catalysis.

Reduction of alkyl nitriles with molecular hydrogen catalyzed by transition-metal complexes is other of these new strategies, which represents a "green" synthesis of aliphatic amines. ${ }^{6}$ As a consequence, a limited number of homogeneous catalysts of $\mathrm{Mn},{ }^{7} \mathrm{Re},{ }^{8} \mathrm{Fe},{ }^{9} \mathrm{Ru},{ }^{10} \mathrm{Co},{ }^{11} \mathrm{Rh},{ }^{12} \mathrm{Ir}^{13}$ and $\mathrm{Pd}^{14}$ have been developed for this reaction. However, it is a scarcely employed procedure due to its several serious drawbacks: somewhat harsh conditions, such as high pressure and elevated temperature, $^{7-10,11 a, c}$ are generally required as well as the need of additives, ${ }^{8,9 b, 11 a, b, 12}$ including strong bases. ${ }^{7,11 c}$ Moreover, the hydrogenation often leads to mixtures of primary, secondary, and tertiary amines, which are generated through hydrogenation-condensation sequences, ${ }^{8,10 a, 13}$ in addition to imine intermediates (Scheme 1). ${ }^{15}$

Osmium catalysts have not been employed up to now for the hydrogenation of nitriles to amines. The use of Os in homogeneous catalysis has been traditionally associated with Sharpless dihydroxylation and reactions akin to that. ${ }^{16}$ Nevertheless, it has been also useful in some other processes of organic synthesis, ${ }^{17}$ including the reduction of unsaturated $\mathrm{C}-\mathrm{C}$ and $\mathrm{C}-\mathrm{O}$ bonds. ${ }^{18}$ Most recently, it has been revealed as a particularly promising alternative for reactions related to the hydrogen economy. ${ }^{18 \mathrm{~d}, 19}$ Particularly remarkable is the

Received: April 3, 2020 
Scheme 1. Hydrogenation-Condensation Sequences for Nitriles

$$
\mathrm{R}-\mathrm{C} \equiv \mathrm{N} \frac{\mathrm{H}_{2}}{\text { cat }} \mathrm{R} \widehat{\mathrm{NH}} \underset{\mathrm{cat}}{\longrightarrow} \mathrm{R} \widehat{\mathrm{H}}_{\mathrm{NH}}
$$

catalytic behavior of the hydroxo derivative $\left[\mathrm{Os}(\mathrm{OH})\left(\eta^{6}-p\right.\right.$ cymene) $\mathrm{IPr}]\left[\mathrm{CF}_{3} \mathrm{SO}_{3}\right]$ (IPr = 1,3-bis(2,6-diisopropylphenyl)imidazolylidene), which has shown to be efficient in the hydrogen transfer from 2-propanol to aldehydes, ${ }^{20}$ the $\alpha$ alkylation of aryl nitriles and methyl ketones, ${ }^{21}$ and the hydration of nitriles to amides. ${ }^{22}$ Other complexes with good performance are its polyhydrides, which have shown their ability to dehydrogenate amine boranes ${ }^{23}$ and liquid organic hydrogen carriers such as alcohols, ${ }^{24}$ cyclic amines, ${ }^{24 c, 25}$ and formic acid. ${ }^{26}$

The $\mathrm{d}^{2}$ hexahydride complex $\mathrm{OsH}_{6}\left(\mathrm{P}^{\mathrm{i}} \mathrm{Pr}_{3}\right)_{2}(\mathbf{1})$ occupies a particularly privileged position among the polyhydrides of platinum-group metals; ${ }^{27}$ its easy synthesis in high yield, ${ }^{28}$ its ability to activate $\sigma$ bonds of a wide range of molecules, ${ }^{29}$ including $\beta$-lactams ${ }^{30}$ and nucleosides, ${ }^{31}$ and its use as a starting point in the preparation of novel Os(II) $)^{32}$ and Os(IV) phosphorescent ${ }^{33}$ emitters have made it one of the cornerstones of the modern stoichiometric chemistry of this element. We now show that is also an efficient and stable catalyst for the selective preparation of symmetrical and asymmetrical secondary amines by means of the hydrogenation of alkyl nitriles, under mild conditions, within reach of the most modest organic chemistry laboratory, without specific equipment for catalysis.

We reported 1 year ago that complex 1 inserts benzonitriles to afford trihydride osmium azavinylidene species. These compounds heterolytically activate $\sigma$ bonds, including molecular hydrogen, to give phenylaldimine derivatives, which undergo a strong stabilization by orthometalation (Scheme 2). ${ }^{34}$ Previously, we had observed that, in contrast

Scheme 2. Reactions of $\mathrm{OsH}_{6}\left(\mathrm{P}^{\mathrm{i}} \mathrm{Pr}_{3}\right)_{2}$ with Benzonitriles

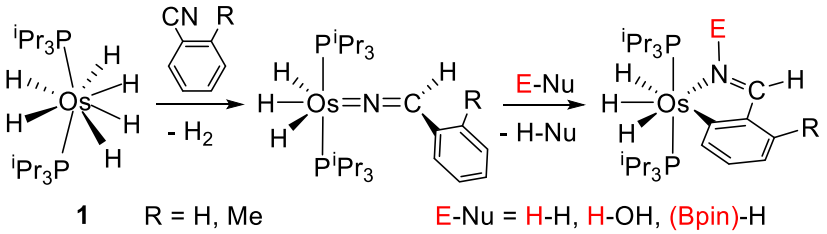

to aromatic nitriles, acetonitrile and propionitrile experience a $\mathrm{C}(\mathrm{sp})-\mathrm{C}\left(\mathrm{sp}^{3}\right)$ bond activation reaction, to release methane and ethane, respectively, and yield the binuclear species $\left(\mathrm{P}^{\mathrm{i}} \mathrm{Pr}_{3}\right)_{2} \mathrm{H}_{4} \mathrm{Os}(\mu-\mathrm{CN}) \mathrm{OsH}_{3}(\mathrm{RCN})\left(\mathrm{P}^{\mathrm{i}} \mathrm{Pr}_{3}\right)_{2} \quad(\mathrm{R}=\mathrm{Me}, \mathrm{Et})$ bearing a $\mathrm{CN}$ bridge (Scheme 3$).{ }^{35}$ In the search to understand the difference in behavior between both classes of nitriles, we delved into the reactions of the hexahydride with alkyl nitriles, discovering that under a hydrogen atmosphere the $\mathrm{C}-\mathrm{C}$ rupture is inhibited and secondary amines resulting from reactions of reduction-condensation-reduction are selectively formed. This paper reports the first osmium catalyst for the hydrogenation of alkyl nitriles to aliphatic amines, the
Scheme 3. Reactions of $\mathrm{OsH}_{6}\left(\mathrm{P}^{\mathrm{i}} \mathrm{Pr}_{3}\right)_{2}$ with Acetonitrile and Propionitrile

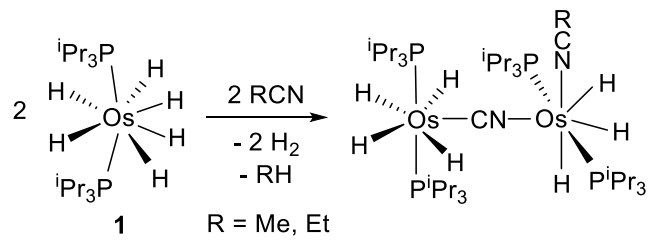

isolation and full characterization of key intermediates of the reactions, and the mechanism of the reduction.

\section{RESULTS AND DISCUSSION}

Reaction Conditions and Scope. We initially tested two very different nitriles, 2-methoxyacetonitrile and 2-phenylacetonitrile, in order to optimize the necessary amount of catalyst to selectively obtain the secondary amines in high yield, in a general manner. The tests were performed with 0.72 M toluene- $d_{8}$ solutions of nitrile, contained in a Fisher-Porter bottle, at $100{ }^{\circ} \mathrm{C}$, and 4 bar of hydrogen (Table 1). Under

\begin{tabular}{|c|c|c|c|c|c|}
\hline entry & nitrile & $\begin{array}{c}1 \\
(\mathrm{~mol} \%)\end{array}$ & $\begin{array}{l}\mathrm{H}_{2} \\
\text { (bar) }\end{array}$ & $\begin{array}{l}\text { time } \\
(\mathrm{h})\end{array}$ & $\begin{array}{c}\text { yield } \\
(\%)^{b}\end{array}$ \\
\hline 1 & $\mathrm{MeO}^{-} \mathrm{CN}$ & 2 & 4 & 24 & 50 \\
\hline 2 & $\mathrm{MeO}^{-} \mathrm{CN}$ & 5 & 4 & 14 & 72 \\
\hline 3 & $\mathrm{MeO} \widehat{\mathrm{CN}}$ & 5 & 4 & 24 & 99 \\
\hline 4 & $\mathrm{Ph} \widehat{C N}$ & 5 & 4 & 24 & 59 \\
\hline 5 & $\mathrm{Ph}_{\mathrm{CN}}$ & 10 & 4 & 24 & 99 \\
\hline
\end{tabular}

Table 1. Optimization for the Catalytic Hydrogenation of Nitriles to Symmetrical Secondary Amines ${ }^{a}$

${ }^{a}$ All reactions were carried out in $0.5 \mathrm{~mL}$ of $\mathrm{C}_{7} \mathrm{D}_{8}$ at $100{ }^{\circ} \mathrm{C}$ with 0.36 mmol of nitrile $(0.72 \mathrm{M}) .{ }^{b}$ Yields were determined by ${ }^{1} \mathrm{H}$ NMR spectroscopy using mesitylene as an internal standard.

these conditions, 2-methoxyacetonitrile is selectively transformed to bis(2-methoxyethyl)amine in $50 \%$ yield, after $24 \mathrm{~h}$, in the presence of $2 \mathrm{~mol} \%$ of complex 1 as catalyst (entry 1 ). The yield of the reaction increases up to $72 \%$ after $14 \mathrm{~h}$ (entry 2 ) and to $99 \%$ after 24 h (entry 3 ) with 5 mol \% of catalyst. In the presence of the same amount of complex 1, diphenethylamine was only obtained in 59\% yield after $24 \mathrm{~h}$ (entry 4 ); therefore, the amount of catalyst was increased until $10 \mathrm{~mol} \%$. Under the new conditions, the transformation of 2-phenylacetonitrile into the secondary amine was almost quantitative (entry 5). In view of these results, we decided to work with 10 mol \% of the catalyst.

Scheme 4 shows the amines generated under the selected conditions. Complex 1 catalyzes the hydrogenation of alkyl nitriles, including substrates with linear chains such as propionitrile and hexanenitrile, aryl-functionalized chains such as 3-phenylpropanenitrile and 2-phenylacetonitriles, and 
Scheme 4. Hydrogenation of Nitriles to Symmetrical Secondary Amines Catalyzed by $1^{a}$

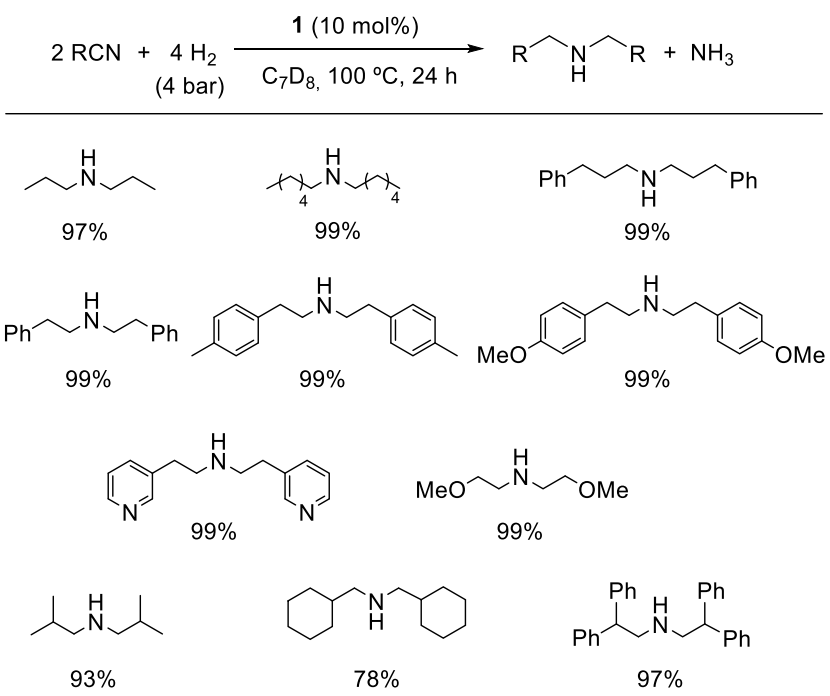

${ }^{a}$ Reaction conditions: nitrile $(0.36 \mathrm{mmol}), 1(0.036 \mathrm{mmol} ; 10 \mathrm{~mol} \%)$ in $0.5 \mathrm{~mL}$ of $\mathrm{C}_{7} \mathrm{D}_{8}, 4$ bar of $\mathrm{H}_{2}$, at $100{ }^{\circ} \mathrm{C}$ for $24 \mathrm{~h}$. Yields were determined by ${ }^{1} \mathrm{H}$ NMR spectroscopy using mesitylene as an internal standard.

pyridyl- and alkoxy-functionalized chains such as 2-(pyridin-3yl)acetonitrile and 2-methoxyacetonitrile. In all the cases the corresponding secondary amines were quantitatively formed after $24 \mathrm{~h}$. Although the formation of the amine is sensitive to the steric hindrance of the substituent of the nitrile, complex 1 is also efficient for the transformation of branched-chain nitriles such as isobutyronitrile, cyclohexanecarbonitrile, and 2,2-diphenylacetonitrile. With these nitriles, secondary amines were obtained in $78-97 \%$ yield after $24 \mathrm{~h}$. Complex 1 also promotes the reduction of pivalonitrile. However, in this case, the reaction displays $65 \%$ of secondary imine (2,2-dimethyl- $N$ neopentylpropan-1-imine), $20 \%$ of primary imine (2,2dimethylpropan-1-imine), and $15 \%$ of primary amine (2,2dimethylpropan-1-amine), after $24 \mathrm{~h}$ (Figure S34). The composition of the mixture indicates that the steric hindrance of the secondary imine prevents its reduction to the corresponding amine. The only metal species detected by NMR spectroscopy at the end of the reactions was, in all cases, the hexahydride complex 1 .

The direct selective formation of secondary aliphatic amines by the hydrogenation of nitriles is comparatively less frequent than the formation of primary amines. Sato, Kayaki, and Ikariya have reported that the cationic half-sandwich $\mathrm{C}, \mathrm{N}$ chelating $\mathrm{Rh}$ complex $\left[\mathrm{Cp} * \mathrm{Rh}(\mathrm{NCMe})\left\{\kappa^{2}-\mathrm{C}, \mathrm{N}-\left(\mathrm{NH}_{2} \mathrm{CPh}_{2}-2-\mathrm{C}_{6} \mathrm{H}_{4}\right)\right\}\right] \mathrm{SbF}_{6}$ also yields secondary amines, in the presence of $\mathrm{AgSbF}_{6}$, under 10 bar of hydrogen, ${ }^{12 \mathrm{~b}}$ whereas Berke and co-workers have observed that a $\operatorname{Re}(\mathrm{I})$ nitrosyl compound efficiently catalyzes the hydrogenation of nitriles to secondary amines, but 50 bar of hydrogen and the presence of $\mathrm{Et}_{3} \mathrm{SiH}$ as an additional additive are necessary in this case. ${ }^{8}$ High hydrogen pressures $(30-60 \mathrm{bar})$ and the presence of additives $\left(\mathrm{NaEt}_{3} \mathrm{BH}, \mathrm{NaOEt}\right.$, or $\mathrm{KO}^{\mathrm{t}} \mathrm{Bu}$ ) are typical experimental conditions for catalysts of 3d metals (Mn, Fe, Co), ${ }^{7,9,11 a, c}$ although Fout and co-workers have observed that a $\mathrm{Co}$ (III) complex bearing a C,C,C-pincer ligand is able to work exceptionally under 4 bar of hydrogen, in the presence of $\mathrm{NaEt}_{3} \mathrm{BH}$ and $\mathrm{KO}^{t} \mathrm{Bu}$. ${ }^{11 \mathrm{~b}}$ Furthermore, the reaction leads to primary amines, since the hydrogenation of the imine is faster than the amine-imine condensation. Catalysts of platinum-group metals need lower pressures. Prechtl and co-workers have reported a $\mathrm{Ru}(\mathrm{II})$ catalyst stabilized by a P,N,P-pincer ligand, which acts under 4 bar of hydrogen but the reaction stops at the secondary imines. ${ }^{10 a}$ The complex $\mathrm{RhH}\left(\mathrm{P}^{\mathrm{i}} \mathrm{Pr}_{3}\right)_{3}$ reduces aromatic and aliphatic nitriles to primary amines under ambient conditions. ${ }^{12 a}$

The ability of $\mathbf{1}$ to hydrogenate imines at a rate slower than that of the imine-amine condensation should allow us to generate asymmetrical secondary amines by introducing an external primary amine in the reaction medium. This catalysis, which has been scarcely explored, ${ }^{10 \mathrm{c}}$ is a promising alternative to the hydroamination of alkenes and alkynes that avoids the regioselectivity problems of these additions and the use of a second catalyst for the reduction of the secondary imines resulting from the $\mathrm{N}-\mathrm{H}$ addition to a $\mathrm{C}-\mathrm{C}$ triple bond. ${ }^{36}$ According to this, once we examined the ability of $\mathbf{1}$ to promote the selective formation of symmetrical secondary aliphatic amines, we decided to study its capacity to generate asymmetrical secondary aliphatic amines. First, we studied the hydrogenation of 2-phenylacetonitrile in the presence of 2methoxyethan-1-amine, under our standard conditions, in order to optimize the necessary amount of external amine, to selectively obtain the asymmetrical secondary amines in high yields (Table 2). When the reaction was performed using a

Table 2. Optimization for the Catalytic Hydrogenation of Nitriles to Asymmetrical Secondary Amines ${ }^{a}$

$$
\text { entry amt of amine, equiv asymmetrical amine, \% symmetrical amine, \% }
$$

${ }^{a}$ Reaction conditions: nitrile $(0.36 \mathrm{mmol})$, catalyst $(0.036 \mathrm{mmol} ; 10$ $\mathrm{mol} \%$ ) in $0.5 \mathrm{~mL}$ of $\mathrm{C}_{7} \mathrm{D}_{8}, 4$ bar of $\mathrm{H}_{2}$, at $100{ }^{\circ} \mathrm{C}$ for $24 \mathrm{~h}$. Yields were determined by ${ }^{1} \mathrm{H}$ NMR spectroscopy using mesitylene as internal standard.

nitrile:amine molar ratio of 1.0:1.0, the symmetrical secondary amine was the major reaction product $(82 \%$; entry 1$)$. However, the selectivity was reversed when nitrile:amine molar ratios of 1.0:2.5 and 1.0:5.0 were used. Under these conditions, 2-methoxy- $N$-phenethylethan-1-amine was quantitatively formed (entries 2 and 3 ). In view of these results, we decided to perform the hydrogenations in the presence of 2.5 equiv of external amine.

Scheme 5 shows the generated asymmetrical secondary amines, which involve the hydrogenation of aliphatic nitriles of linear unfunctionalized and aryl- and alkoxy-functionalized chains in the presence of primary alkylamines with linear phenyl- and alkoxy-functionalized chains and branched-chain amines. These classes of amines include butan-1-amine, phenylmethanamine, 2-methoxyethan-1-amine, and cyclohexanamine, respectively. All secondary amines were formed in high yields of $70-99 \%$, after $24 \mathrm{~h}$ of reaction.

Reactions of 1 with Pivalonitrile and 2-Methoxyacetonitrile under an Argon Atmosphere. Having demonstrated the ability of $\mathbf{1}$ to promote the formation of 
Scheme 5. Hydrogenation of Nitriles to Asymmetrical Secondary Amines Catalyzed by $1^{a}$

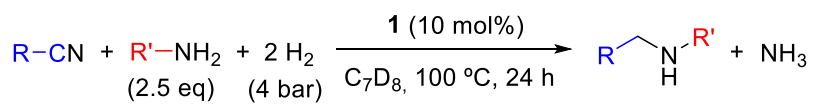

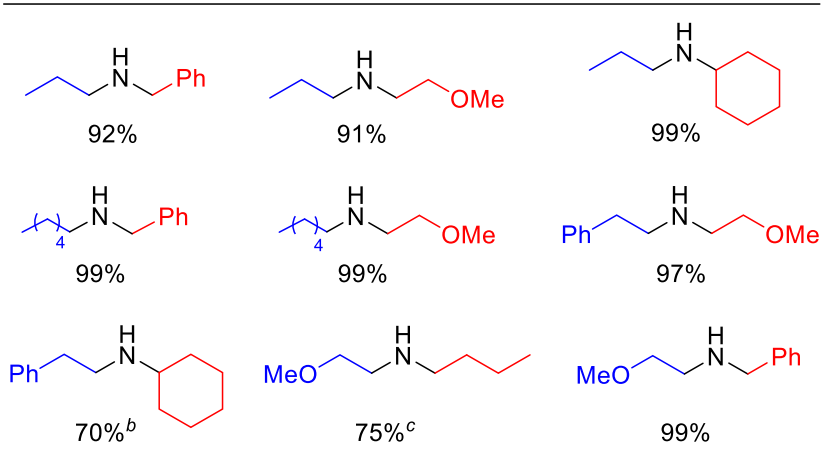

${ }^{a}$ Reaction conditions: nitrile $(0.36 \mathrm{mmol})$, amine $(0.90 \mathrm{mmol}), 1$ $(0.036 \mathrm{mmol} ; 10 \mathrm{~mol} \%)$ in $0.5 \mathrm{~mL}$ of $\mathrm{C}_{7} \mathrm{D}_{8}, 4$ bar of $\mathrm{H}_{2}$, at $100{ }^{\circ} \mathrm{C}$ for $24 \mathrm{~h}$. Yields were determined by ${ }^{1} \mathrm{H}$ NMR spectroscopy using mesitylene as an internal standard. ${ }^{2} 29 \%$ of symmetrical secondary amine is also formed. ${ }^{c} 24 \%$ of symmetrical secondary amine is also formed.

symmetrical and asymmetrical secondary aliphatic amines by means of the hydrogenation of alkyl nitriles, we decided to study the reactions of the catalyst with the title nitriles, under an argon atmosphere, to gain mechanistic insight into the catalysis and to understand why the rupture of the $\mathrm{C}(\mathrm{sp})-$ $\mathrm{C}\left(\mathrm{sp}^{3}\right)$ bond of the nitriles now does not take place. Pivalonitrile was selected because its hydrogenation and subsequent condensation to a secondary imine were the most difficult and, at first glance, seems to be the most appropriate for the isolation of catalytic intermediates. On the other hand, the presence of an alkoxy substituent at 2methoxyacetonitrile should favor the rupture of its $\mathrm{C}(\mathrm{sp})-$ $\mathrm{C}\left(\mathrm{sp}^{3}\right)$ bond.

The warming of a toluene solution of 1 , at $130{ }^{\circ} \mathrm{C}$, in the presence of 1.0 equiv of pivalonitrile initially gives rise to the release of a hydrogen molecule from the starting compound, to afford the unsaturated tetrahydride intermediate $\mathrm{OsH}_{4}\left(\mathrm{P}^{\mathrm{i}} \mathrm{Pr}_{3}\right)_{2}$ (A), which is trapped by the nitrile. The resulting saturated tetrahydride $\mathrm{OsH}_{4}\left\{\kappa^{1}-\mathrm{N}-\left(\mathrm{N} \equiv \mathrm{C}^{\mathrm{t}} \mathrm{Bu}\right)\right\}\left(\mathrm{P}^{\mathrm{i}} \mathrm{Pr}_{3}\right)_{2}$ (2) is unstable and evolves to the trihydride azavinylidene derivative $\mathrm{OsH}_{3}(=$ $\left.\mathrm{N}=\mathrm{CH}^{\mathrm{t}} \mathrm{Bu}\right)\left(\mathrm{P}^{\mathrm{i}} \mathrm{Pr}_{3}\right)_{2}$ (3). According to this, a 35:65 mixture of 2 and 3 is formed after $3 \mathrm{~h}$. Under molecular hydrogen ( 1 bar, $100{ }^{\circ} \mathrm{C}, 10 \mathrm{~min}$ ), the mixture of 2 and 3 regenerates 1 and gives 2,2-dimethylpropan-1-imine (Figures S69 and S70), to close a stoichiometric cycle for the hydrogenation of the nitrile (Scheme 6). No evidence for the formation of binuclear compounds related to those shown in Scheme 3 was found. The cycle shown in Scheme 6 is strong evidence in favor of the participation of trihydride azavinylidene derivatives, related to 3 , as key intermediates in the hydrogenations shown in Schemes 4 and 5.

The spectroscopic features of 2 are a triplet $\left({ }^{2} J_{\mathrm{H}-\mathrm{P}}=13.2\right.$ $\mathrm{Hz}$ ) at $-9.98 \mathrm{ppm}$ in the ${ }^{1} \mathrm{H}$ NMR spectrum due to the hydride ligands, which are involved in a thermally activated position exchange process, in agreement with that previously observed for the related compound $\mathrm{OsH}_{4}\left\{\kappa^{1}-N-[\mathrm{N} \equiv \mathrm{C}(2,6-\right.$ $\left.\left.\left.\mathrm{C}_{6} \mathrm{H}_{3} \mathrm{Me}_{2}\right)\right]\right\}\left(\mathrm{P}^{\mathrm{i}} \mathrm{Pr}_{3}\right)_{2},{ }^{34}$ and a singlet at $43.1 \mathrm{ppm}$ in the ${ }^{31} \mathrm{P}\left\{{ }^{1} \mathrm{H}\right\}$ NMR spectrum. In contrast to 2 , the hydride ligands of 3 give rise to three resonances at $-9.86,-11.57$, and -13.56
Scheme 6. Stoichiometric Cycle for the Hydrogenation of Pivalonitrile in the Presence of 1

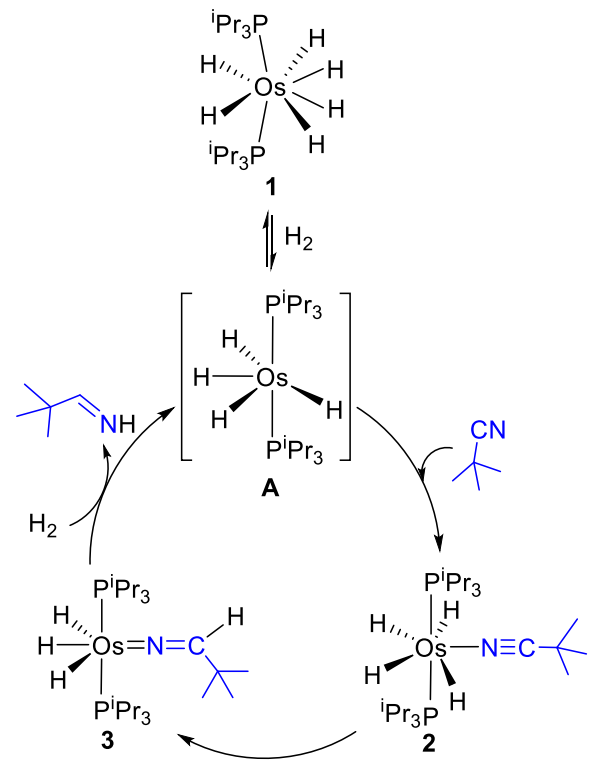

ppm in the ${ }^{1} \mathrm{H}$ NMR spectrum, whereas the ${ }^{31} \mathrm{P}\left\{{ }^{1} \mathrm{H}\right\}$ NMR spectrum displays a singlet at $37.3 \mathrm{ppm}$. Crystals suitable for the X-ray diffraction analysis of 3 were obtained from the mixture. The structure (Figure 1), which confirms the

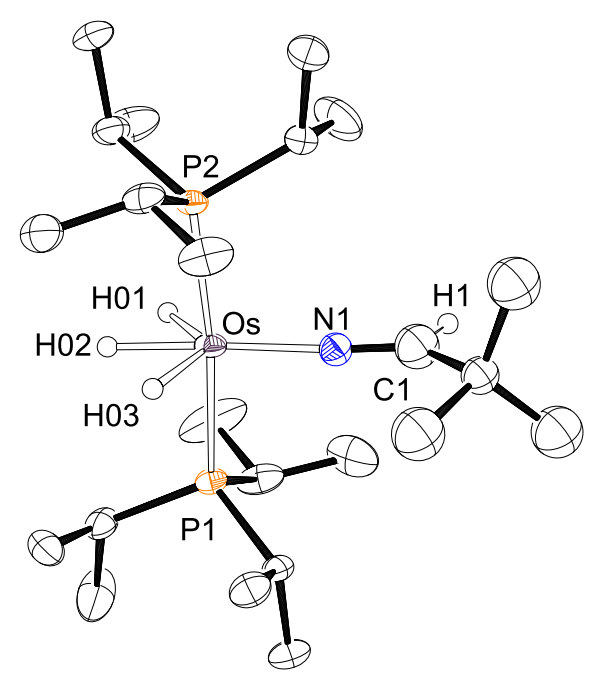

Figure 1. Molecular structure of complex 3 (ellipsoids are drawn at the $50 \%$ probability level). Hydrogen atoms of the phosphine ligands and tert-butyl group are omitted for clarity. Selected bond distances $(\AA)$ and angles (deg): Os-P(1) = 2.3362(7), Os-P $(2)=2.3359(7)$, $\mathrm{Os}-\mathrm{N}(1)=1.922(3) ; \mathrm{P}(1)-\mathrm{Os}-\mathrm{P}(2)=173.31(3)$.

trihydride azavinylidene nature of the molecule, displays $C_{s}$ symmetry with trans phosphines $(\mathrm{P}(1)-\mathrm{Os}-\mathrm{P}(2)=$ $\left.173.31(3)^{\circ}\right)$, as expected for a six-coordinate $\mathrm{d}^{4} \mathrm{OsH}_{3} \mathrm{XL}_{2}$ species. $^{34,37}$

The reaction of $\mathbf{1}$ with 2-methoxyacetonitrile shows significant differences with regard to that with pivalonitrile, which are consistent with a faster hydrogenation of the nitrile and a higher tendency to undergo $\mathrm{C}(\mathrm{sp})-\mathrm{C}\left(\mathrm{sp}^{3}\right)$ bond rupture. It was performed in closed NMR tubes and was followed by ${ }^{1} \mathrm{H}$ and ${ }^{31} \mathrm{P}\left\{{ }^{1} \mathrm{H}\right\}$ NMR spectroscopy at 50 and 80 ${ }^{\circ} \mathrm{C}$ (Figures S69-S72). The warming of toluene- $d_{8}$ solutions of 
1 , at $80{ }^{\circ} \mathrm{C}$, in the presence of 1.0 equiv of 2 methoxyacetonitrile affords three Os compounds, the trihydride azavinylidene derivative $\mathrm{OsH}_{3}\left(=\mathrm{N}=\mathrm{CHCH}_{2} \mathrm{OMe}\right)$ $\left(\mathrm{P}^{\mathrm{i}} \mathrm{Pr}_{3}\right)_{2}$ (4) and the binuclear complexes $\left(\mathrm{P}^{\mathrm{i}} \mathrm{Pr}_{3}\right)_{2} \mathrm{H}_{4} \mathrm{Os}(\mu$ $\mathrm{CN}) \mathrm{OsH}_{3}\left\{\kappa^{1}-\mathrm{N}-\left(\mathrm{NH}=\mathrm{CHCH}_{2} \mathrm{OMe}\right)\right\}\left(\mathrm{P}^{\mathrm{i}} \mathrm{Pr}_{3}\right)_{2} \quad(5)$ and $\left(\mathrm{P}^{\mathrm{i}} \mathrm{Pr}_{3}\right)_{2} \mathrm{H}_{4} \mathrm{Os}(\mu-\mathrm{CN}) \mathrm{OsH}_{3}\left\{\kappa^{1}-N-\left(\mathrm{NH}_{2} \mathrm{CH}_{2} \mathrm{CH}_{2} \mathrm{OMe}\right)\right\}-$ $\left(\mathrm{P}^{\mathrm{i}} \mathrm{Pr}_{3}\right)_{2}$ (6), bearing an imine and an amine ligand, respectively, generated from the hydrogenation of the nitrile. Figure 2 shows the course of the transformation as a function of time.

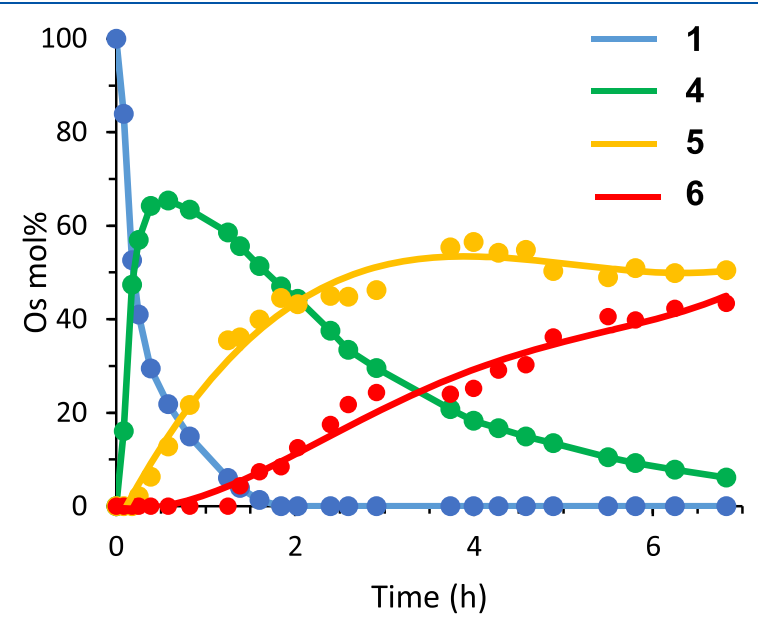

Figure 2. Profile for the progress of the reaction of 1 with 2methoxyacetonitrile $(1: 1$ molar ratio; both $0.1 \mathrm{M})$ in toluene- $d_{8}$ at 80 ${ }^{\circ} \mathrm{C}$.

The trihydride azavinylidene derivative $\mathbf{4}$ is the first metal complex formed and is the major product at the beginning of the reaction. At $50{ }^{\circ} \mathrm{C}$, it reaches $88 \%$ of the total osmium after $25 \mathrm{~h}$ and can be isolated from the mixture as a yellow oil. Its ${ }^{1} \mathrm{H}$ and ${ }^{31} \mathrm{P}\left\{{ }^{1} \mathrm{H}\right\}$ NMR spectra agree well with those of the pivalonitrile counterpart 3 . Thus, the ${ }^{1} \mathrm{H}$ NMR spectrum displays three hydride resonances at $-11.23,-11.57$, and -11.66 ppm, whereas ${ }^{31} \mathrm{P}\left\{{ }^{1} \mathrm{H}\right\}$ shows a singlet at $38.2 \mathrm{ppm}$. According to Scheme 6, complex 4 is the source of the imine ligand of $\mathbf{5}$, since it should react with the molecular hydrogen released in the formation of the tetrahydride intermediate $\mathbf{A}$, responsible for its formation (route a in Scheme 7). The unsaturated tetrahydride A should also promote the hydrogenation of a part of the generated imine to afford the amine ligand of 6 (route b in Scheme 7). The profile of the curves shown in Figure 2 suggests that the binuclear skeleton of $\mathbf{5}$ and $\mathbf{6}$ is the consequence of the attack of $\mathbf{A}$ to the $\mathrm{C}\left(\mathrm{sp}^{2}\right)$ atom of the azavinylidene ligand of 4 (route $c$ in Scheme 7 ), which could give the binuclear intermediate $\mathbf{B}$, releasing dimethyl ether. A subsequent $C$ to Os 1,2-hydrogen shift should afford C, which could yield $\mathbf{5}$ and $\mathbf{6}$ by coordination of the imine and amine generated in the hydrogenation processes (routes a and b). The higher steric hindrance of the tert-butyl group with regard to $-\mathrm{CH}_{2} \mathrm{OMe}$, which prevents the approach of $\mathbf{A}$ to the $\mathrm{C}\left(\mathrm{sp}^{2}\right)$ atom of the azavinylidene, could explain why 3 does not give binuclear species. The formation of 5 and 6 is inhibited under a hydrogen atmosphere. This inhibition may be due to the decrease in the concentration of the tetrahydride $\mathbf{A}$ and/or the increase in the rate of hydrogenation of $\mathbf{4}$. The fact that $\mathbf{1}$ is the only spectroscopically detected species in the hydrogenation reactions and the high yield of the obtained products in the catalysis rule out the mediation of the binuclear species in the catalytic cycles, since the construction of the binuclear skeleton involves the loss of 0.5 equiv of substrate per 1 equiv of catalyst.

Crystals suitable for X-ray diffraction analysis of 5 and 6 were obtained from the crude reaction mixture. The respective structures (Figures 3 and 4) prove the binuclear character of these complexes and confirm the presence of the linear Os $(1)-\mathrm{N}(1)-\mathrm{C}(1)-\mathrm{Os}(2)$ bridge, which displays Os(1)$\mathrm{N}(1)-\mathrm{C}(1)$ and $\mathrm{N}(1)-\mathrm{C}(1)-\mathrm{Os}(2)$ angles of $171.2(6)$ and $179.6(9)^{\circ}$ for 5 and $178.2(5)$ and $178.9(6)^{\circ}$ for 6 and a

Scheme 7. Stoichiometric Reactions of 1 with 2-Methoxyacetonitrile under Argon

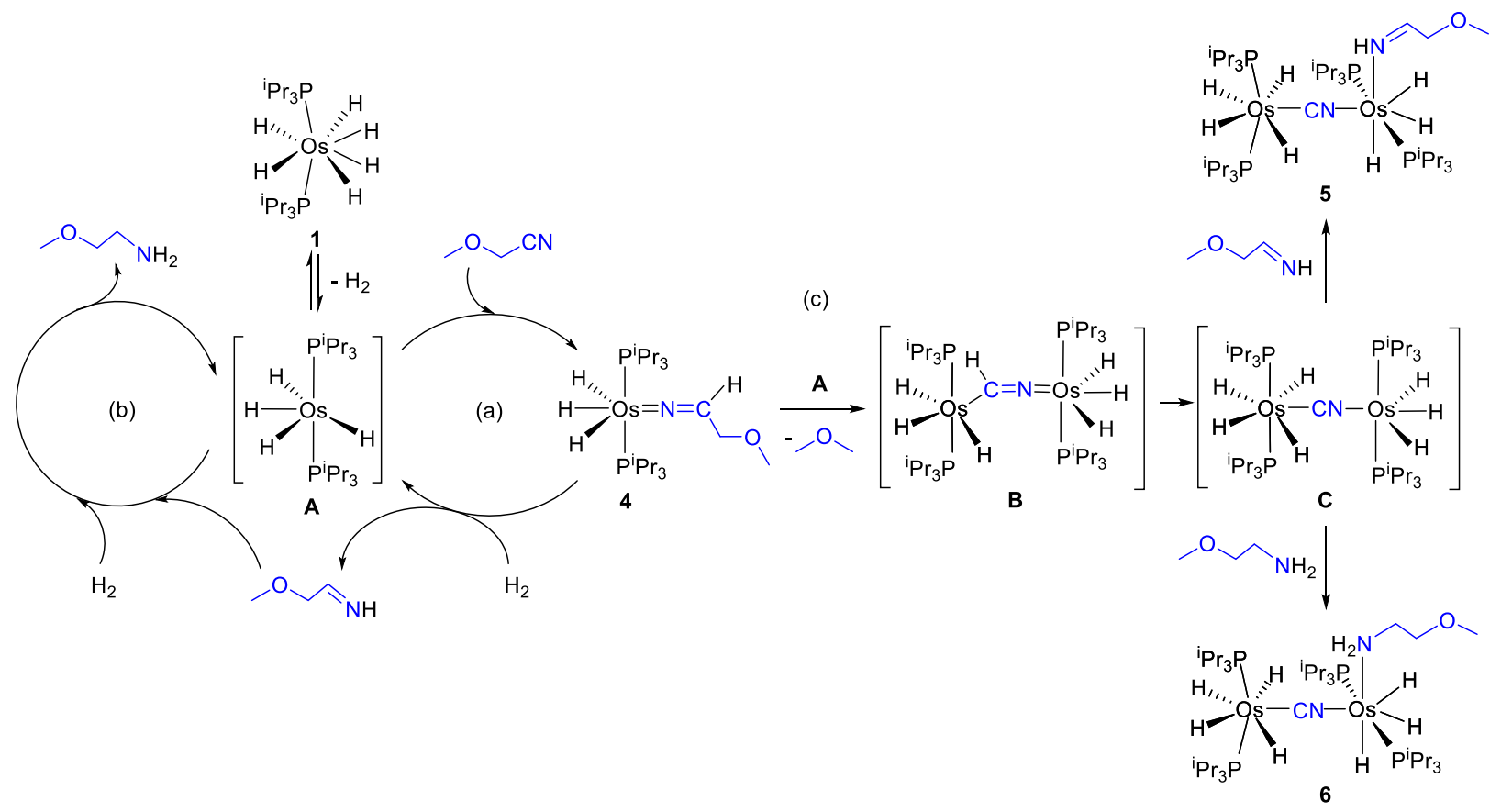




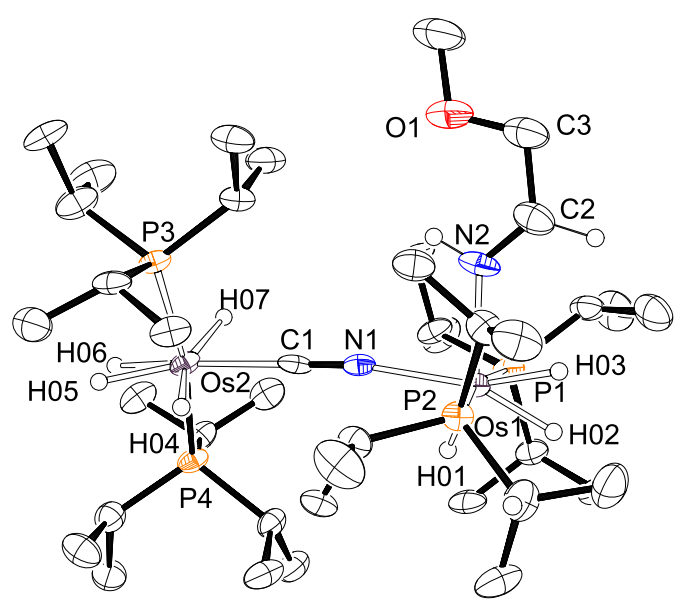

Figure 3. Molecular structure of complex 5 (ellipsoids are drawn at the $50 \%$ probability level). Hydrogen atoms except for hydrides and those attached to nitrogen and $\mathrm{C}_{\alpha}$ atoms of the imine ligand are omitted for clarity. Selected bond distances $(\AA)$ and angles (deg): $\mathrm{Os}(1)-\mathrm{N}(1)=2.142(8), \operatorname{Os}(1)-\mathrm{N}(2)=2.150(8), \mathrm{Os}(2)-\mathrm{C}(1)=$ 2.051(10), $\mathrm{N}(1)-\mathrm{C}(1)=1.171(12), \mathrm{N}(2)-\mathrm{C}(2)=1.275(14)$; $\mathrm{Os}(1)-\mathrm{N}(1)-\mathrm{C}(1)=171.2(6), \mathrm{N}(1)-\mathrm{C}(1)-\mathrm{Os}(2)=179.6(9)$, $\mathrm{P}(1)-\mathrm{Os}(1)-\mathrm{P}(2)=170.86(8), \mathrm{P}(3)-\mathrm{Os}(2)-\mathrm{P}(4)=170.40(9)$.

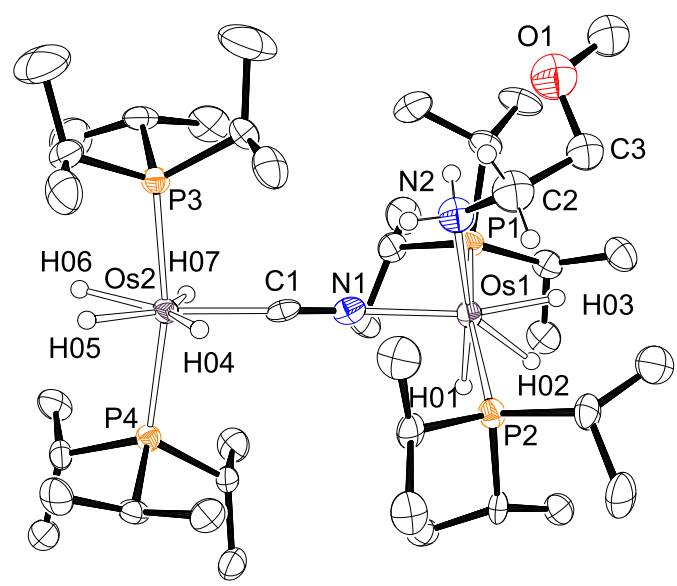

Figure 4. Molecular structure of complex 6 (ellipsoids are drawn at the $50 \%$ probability level). Hydrogen atoms except for hydrides and those attached to nitrogen and $\mathrm{C}_{\alpha}$ atoms of the amine are omitted for clarity. Selected bond distances $(\AA)$ and angles $(\mathrm{deg})$ : Os $(1)-\mathrm{N}(1)=$ 2.136(6), Os(1) $-\mathrm{N}(2)=2.226(8), \mathrm{Os}(2)-\mathrm{C}(1)=2.057(7), \mathrm{N}(1)-$ $\mathrm{C}(1)=1.165(7), \mathrm{N}(2)-\mathrm{C}(2)=1.480(13) ; \mathrm{Os}(1)-\mathrm{N}(1)-\mathrm{C}(1)=$ 178.2(5), $\mathrm{N}(1)-\mathrm{C}(1)-\mathrm{Os}(2)=178.9(6), \mathrm{P}(1)-\mathrm{Os}(1)-\mathrm{P}(2)=$ 163.94(6), $\mathrm{P}(3)-\mathrm{Os}(2)-\mathrm{P}(4)=168.32(6)$.

$\mathrm{N}(1)-\mathrm{C}(1)$ bond length of 1.171(12) $\AA$ for 5 and 1.165(7) $\AA$ for 6 , in agreement with the previously reported acetonitrile derivative $\left(\mathrm{P}^{\mathrm{i}} \mathrm{Pr}_{3}\right)_{2} \mathrm{H}_{4} \mathrm{Os}(\mu-\mathrm{CN}) \mathrm{OsH}_{3}\left\{\kappa^{1} N-(\mathrm{N} \equiv \mathrm{CMe})\right\}$ $\left(\mathrm{P}^{\mathrm{i}} \mathrm{Pr}_{3}\right)_{2}{ }^{35}$ The coordination polyhedra around the osmium atoms can be rationalized as distorted pentagonal bipyramids with axial phosphines $\left(\mathrm{P}(1)-\mathrm{Os}(1)-\mathrm{P}(2)=170.86(8)^{\circ}\right.$ and $\mathrm{P}(3)-\mathrm{Os}(2)-\mathrm{P}(4)=170.40(9)^{\circ}$ for 5 and $\mathrm{P}(1)-\mathrm{Os}(1)-$ $\mathrm{P}(2)=163.94(6)^{\circ}$ and $\mathrm{P}(3)-\mathrm{Os}(2)-\mathrm{P}(4)=168.32(6)^{\circ}$ for $6)$. The equatorial planes form an angle of $77(2)^{\circ}$ for 5 and $67(1)^{\circ}$ for 6 . According to the presence of $\mathrm{OsH}_{4} \mathrm{P}_{2}$ and $\mathrm{OsH}_{3} \mathrm{P}_{2}$ moieties, the ${ }^{1} \mathrm{H}$ NMR spectra, in toluene- $d_{8}$, at room temperature contain two hydride resonances in a 4:3 intensity ratio at -10.37 and $-11.78 \mathrm{ppm}$ for 5 and at -10.56 and $-12.98 \mathrm{ppm}$ for 6 , whereas the ${ }^{31} \mathrm{P}\left\{{ }^{1} \mathrm{H}\right\}$ NMR spectra contain two signals at around 44 and $24 \mathrm{ppm}$, in approximately a 1:1 intensity ratio.

DFT Study of the Hydrogenation Mechanism. The products of the reactions of 1 with both pivalonitrile and 2methoxyacetonitrile, complexes 3 and 4, are overwhelming experimental evidence supporting that the trihydride azavinylidene derivatives $\mathrm{OsH}_{3}(=\mathrm{N}=\mathrm{CHR})\left(\mathrm{P}^{\mathrm{i}} \mathrm{Pr}_{3}\right)_{2}$ act as key intermediates in the hydrogenation of the alkyl nitriles to the corresponding primary imines (Schemes 6 and 7a). Nevertheless, there are two points that still need to be clarified: the formation of these intermediates and their reaction with molecular hydrogen. To gain insight into them, we carried out DFT calculations (B3LYP-D3/SDD/6-31G**) using propionitrile as the substrate model. The changes in free energy $(\Delta G)$ were calculated in toluene at $298.15 \mathrm{~K}$ and 1 atm.

Two coordination modes have been observed for nitrile ligands: $\kappa^{1}-\mathrm{N}^{38}$ and $\eta^{2}-\mathrm{C} \equiv \mathrm{N}^{39}$ As a consequence, two different paths for the azavinylidene formation are possible in principle: a 1,3-hydrogen shift, similar to that proposed for the isomerization of hydride metal alkynyl species into vinylidene complexes, ${ }^{40}$ and 1,2-hydrogen migration from the metal to the carbon atom of the coordinated triple bond. ${ }^{41}$ Previous DFT calculations on the formation of the phenylazavinylidene derivative $\mathrm{OsH}_{3}(=\mathrm{N}=\mathrm{CHPh})\left(\mathrm{P}^{\mathrm{i}} \mathrm{Pr}_{3}\right)_{2}$ revealed a much higher activation energy for the 1,3-hydrogen shift than for the 1,2-hydrogen migration (64.4 versus $17.2 \mathrm{kcal} \mathrm{mol}^{-1}$ ), even though the intermediate $\mathrm{OsH}_{4}\left(\eta^{2}-\mathrm{N} \equiv \mathrm{CPh}\right)\left(\mathrm{P}^{\mathrm{i}} \mathrm{Pr}_{3}\right)_{2}$ is 14.9 $\mathrm{kcal} \mathrm{mol}{ }^{-1}$ less stable than the species $\mathrm{OsH}_{4}\left(\kappa^{1}-\mathrm{N} \equiv \mathrm{CPh}\right)$ $\left(\mathrm{P}^{\mathrm{i}} \mathrm{Pr}_{3}\right)_{2}{ }^{34}$ The replacement of the phenyl substituent of the nitrile by an ethyl group modifies the situation. Although the relative stability of the $\kappa^{1}-\mathrm{N}$ and $\eta^{2}-\mathrm{C} \equiv \mathrm{N}$ forms does not significantly change, the activation energy for the 1,3-hydrogen shift dramatically decreases with regard to that reported for the aromatic nitrile. As a consequence, the 1,3-hydrogen shift (Figure 5) is now slightly favored with regard to the 1,2hydrogen migration (15.8 versus $16.9 \mathrm{kcal} \mathrm{mol}^{-1}$ ). Both hydrogen shifts lead to the intermediate $\mathbf{t}_{1}$, which is between 14.8 and $15.3 \mathrm{kcal} \mathrm{mol}^{-1}$ less stable than the saturated tetrahydride $t_{0}$, the ethyl counterpart of 2 . It can be described

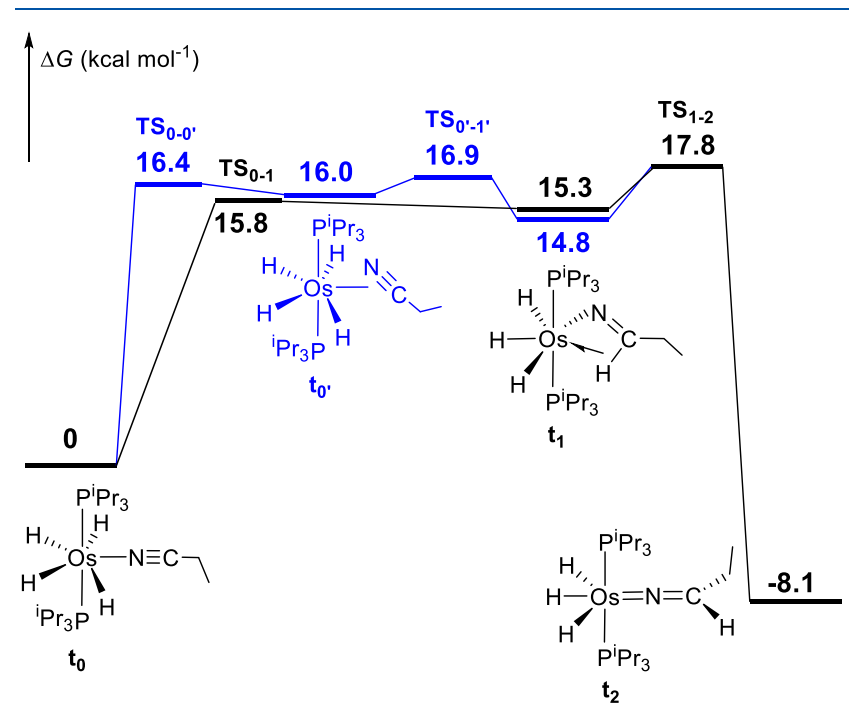

Figure 5. Computed energy profile for the formation of the model azavinylidene $\mathrm{OsH}_{3}(=\mathrm{N}=\mathrm{CHEt})\left(\mathrm{P}^{\mathrm{i}} \mathrm{Pr}_{3}\right)_{2} \quad\left(\mathbf{t}_{2}\right)$ via a 1,3-hydrogen shift (black -) or via 1,2-hydrogen migration on a $\eta^{2}-\mathrm{CN}$ intermediate (blue -). 
as a propylideneamido compound, which saturates the electron deficiency of the metal center with an Os-H-C agostic interaction. The breakage of this interaction and the opening of the Os-N-C bond angle afford the azavinylidene $t_{2}$, the ethyl counterpart of complexes 3 and 4 , with a barrier of 2.5 $\mathrm{kcal} \mathrm{mol}{ }^{-1}$. The trihydride azavinylidene $t_{2}$ is $8.1 \mathrm{kcal} \mathrm{mol}^{-1}$ more stable than $\mathbf{t}_{\mathbf{0}}$.

The reaction of the azavinylidene intermediate $t_{2}$ with hydrogen is the stage of the highest barrier in the nitrile to imine hydrogenation process. Its course is a function of the asymmetry of the azavinylidene ligand, since two approaches of the hydrogen molecule to the Os-N bond are possible in the azavinylidene plane: entry by the ethyl substituent side or by the $\mathrm{C}-\mathrm{H}$ hydrogen atom side. The latter is slightly favored (Figure 6; 27.8 versus $28.3 \mathrm{kcal} \mathrm{mol}^{-1}$ ) 42 and involves an

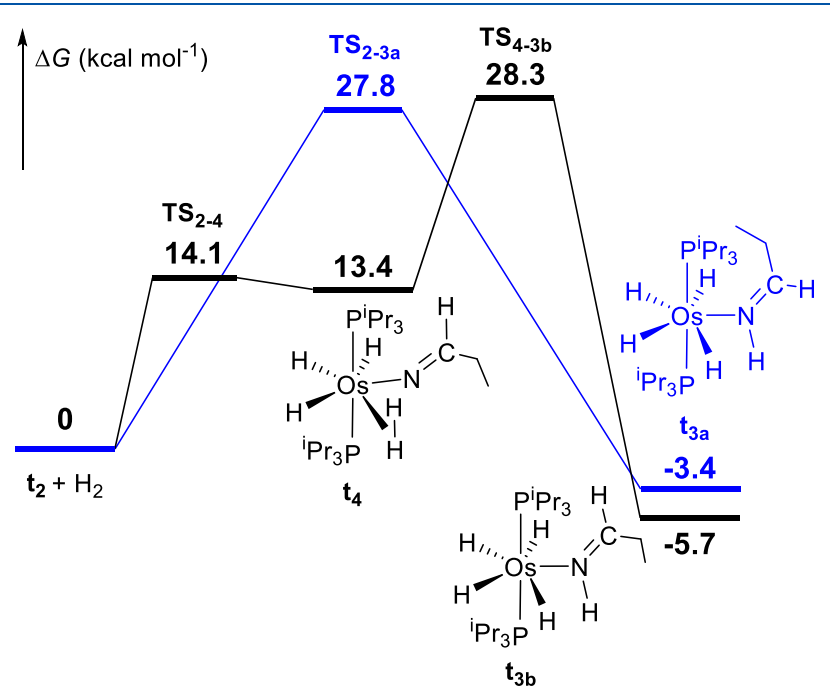

Figure 6. Computed energy profile for the reaction of the model azavinylidene $\mathbf{t}_{\mathbf{2}}$ with $\mathrm{H}_{2}$ : outer sphere (blue - ) and inner sphere via a dihydrogen intermediate (black - ).

outer-sphere step, which affords the tetrahydride $\mathbf{t}_{3 \mathrm{a}}$ with a coordinated primary cis-imine. In contrast to the entry by the $\mathrm{C}-\mathrm{H}$ hydrogen side, the approach of the hydrogen molecule by the ethyl group side generates the Kubas-type dihydrogen intermediate $\mathbf{t}_{4}\left(d_{\mathrm{H}-\mathrm{H}}=0.842 \AA\right)$, which is $13.4 \mathrm{kcal} \mathrm{mol}^{-1}$ less stable than $t_{2}$. The subsequent migration of one of the atoms of the dihydrogen ligand to the nitrogen atom leads to $t_{3 b}$, related to $t_{3 a}$ but bearing a trans-imine. The dissociation of the imine from $\mathbf{t}_{3}$ regenerates the tetrahydride $\mathbf{A}$, closing the cycle for the hydrogenation of the nitrile to the primary imine.

Once we clarified the hydrogenation of the nitrile to the primary imine, we calculated the imine to amine hydrogenation. Because the nitrile to imine and imine to amine hydrogenations should be similar processes, we assumed that the key intermediates of the imine to amine hydrogenation are $\mathrm{OsH}_{3}(=\mathrm{NHR})\left(\mathrm{P}^{\mathrm{i}} \mathrm{Pr}_{3}\right)_{2}$, amido counterparts of the azavinylidene derivatives. Accordingly, we divided the process into two stages: imine insertion (Figure 7) and reaction of the amido intermediate with molecular hydrogen (Figure 8).

The migration of one of the hydride ligands of both $\mathbf{t}_{3 \mathbf{a}}$ (cisimine) and $t_{3 b}$ (trans-imine) to the $C\left(\mathrm{sp}^{2}\right)$ atom of the coordinated imine initially affords $\mathbf{t}_{5}$, which is 14.9 and 17.5 $\mathrm{kcal} \mathrm{mol}{ }^{-1}$ less stable than $\mathbf{t}_{3 \mathrm{a}}$ and $\mathbf{t}_{3 \mathrm{~b}}$, respectively. However, the Os to $\mathrm{C}$ migration depends upon the stereochemistry of the imine. While the insertion of the cis-imine takes place

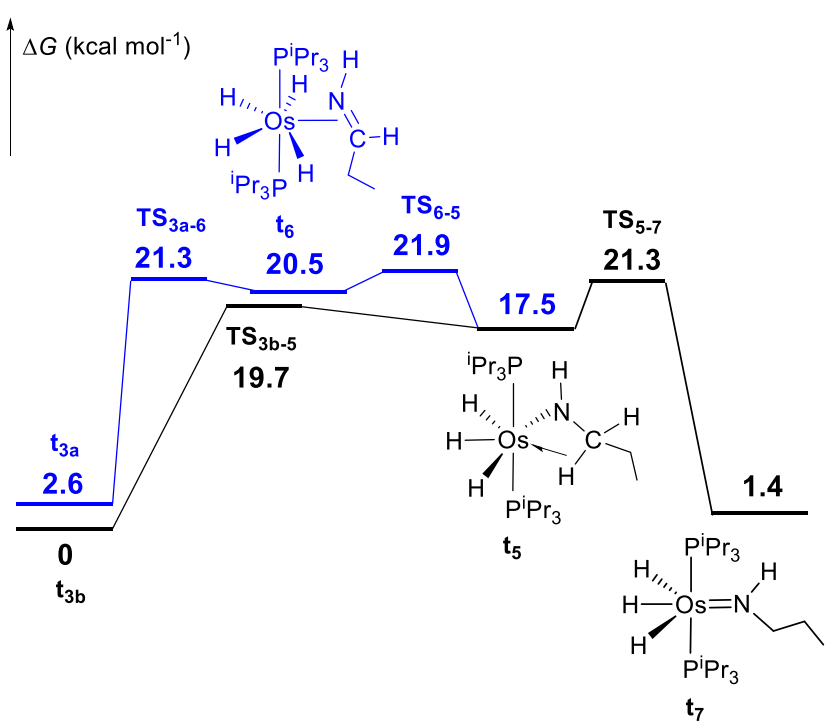

Figure 7. Computed energy profile for the insertion of the imine ligand into one of the Os-H bonds of $\mathbf{t}_{3 \mathrm{a}}$ (cis-imine) and $\mathbf{t}_{3 \mathrm{~b}}$ (transimine).

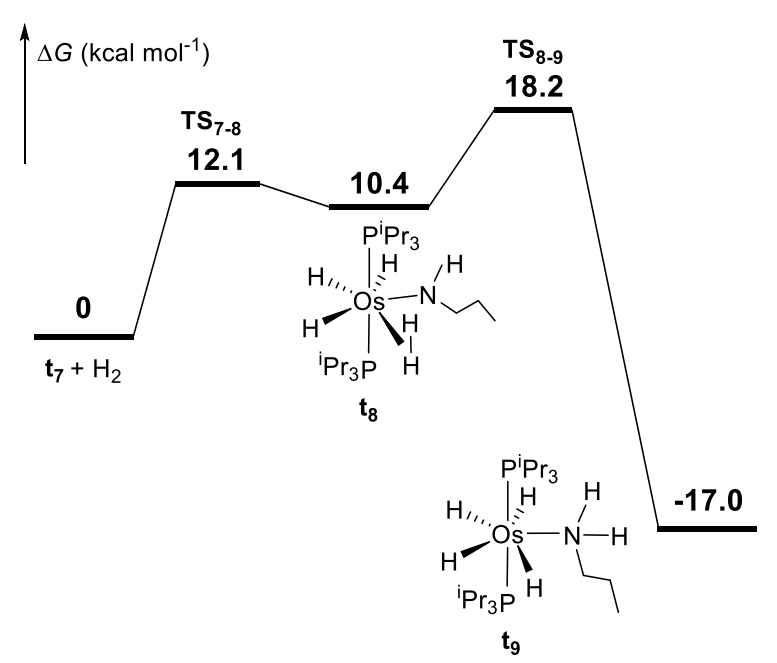

Figure 8. Computed energy profile for the reaction of the $n$ propylamido intermediate $\mathrm{OsH}_{3}\left(=\mathrm{NH}^{\mathrm{n}} \mathrm{Pr}\right)\left(\mathrm{P}^{\mathrm{i}} \mathrm{Pr}_{3}\right)_{2}\left(\mathbf{t}_{7}\right)$ with $\mathrm{H}_{2}$.

through an 1,2-hydrogen shift via the $\eta^{2}$-imine intermediate $\mathbf{t}_{6}$, the insertion of the trans-imine occurs in one step by a 1,3hydrogen shift. The first path is slightly favored with regard to the second ( 19.3 versus $19.7 \mathrm{kcal} \mathrm{mol}^{-1}$ ). Like $\mathbf{t}_{1}$, intermediate $\mathbf{t}_{\mathbf{5}}$ saturates the electron deficiency of the metal center with an $\mathrm{Os}-\mathrm{H}-\mathrm{C}$ agostic interaction. The rupture of the $\mathrm{Os}-\mathrm{H}$ interaction affords the $n$-propylamido derivative $\mathbf{t}_{7}$, with a barrier of $3.8 \mathrm{kcal} \mathrm{mol}^{-1}$. Intermediate $t_{7}$ is $1.4 \mathrm{kcal} \mathrm{mol}^{-1}$ less stable than $t_{3 b}$ and $1.2 \mathrm{kcal} \mathrm{mol}^{-1}$ more stable than $\mathrm{t}_{3 \mathrm{a}}$.

The main difference between the amido $t_{7}$ and the azavinylidene $t_{2}$ is the disposition of the $\mathrm{N}$-donor ligand. In contrast to the azavinylidene group, the $n$-propylamido ligand lies in the same plane as the $\mathrm{P}-\mathrm{Os}-\mathrm{P}$ direction; as a consequence, the hydrogen molecule has only one way of approaching the $\mathrm{Os}-\mathrm{N}$ bond. This approach initially leads to the Kubas-type dihydrogen species $\mathbf{t}_{8}\left(d_{\mathrm{H}-\mathrm{H}}=0.861 \AA\right)$, which is only $10.4 \mathrm{kcal} \mathrm{mol}^{-1}$ less stable than $\mathbf{t}_{7}$. This dihydrogen compound is the propylamido counterpart of $\mathbf{t}_{4}$. Like the latter, it undergoes an Os to $\mathrm{N}$ migration of one of the atoms of the coordinated hydrogen molecule, to directly afford the 
tetrahydride amine derivative $\mathbf{t}_{9}$ with a barrier of $18.2 \mathrm{kcal}$ $\mathrm{mol}^{-1}$, with regard to $t_{7}$ : i.e., around $10 \mathrm{kcal} \mathrm{mol}^{-1}$ lower than that shown in Figure 6 for the transformation of $\mathbf{t}_{\mathbf{2}}$ into $\mathbf{t}_{\mathbf{3}}$. The dissociation of the amine from $\mathbf{t}_{\mathbf{9}}$ regenerates the tetrahydride A.

\section{CONCLUDING REMARKS}

This study has revealed that the previously reported $\mathrm{C}-\mathrm{C}$ rupture of alkyl nitriles, which is promoted by the $\mathrm{d}^{2}$ hexahydride complex $\mathrm{OsH}_{6}\left(\mathrm{P}^{\mathrm{i}} \mathrm{Pr}_{3}\right)_{2}$ under an argon atmosphere, is inhibited under molecular hydrogen. In toluene, at $100{ }^{\circ} \mathrm{C}$, this polyhydride catalyzes the hydrogenation of the nitriles, under 4 bar of hydrogen, to give symmetrical secondary aliphatic amines. The scope of substrates includes aryl-, pyridyl-, and alkoxy-functionalized alkyl nitriles with linear or branched chains. The secondary amines are the result of the formation of primary imines and amines, which condense to afford secondary imines, under the reaction conditions. The subsequent hydrogenation of these imines finally yields the secondary amines. The condensation is faster than the imine hydrogenation; as a consequence, the introduction of an external primary alkylamine in the reaction medium allows the generation of asymmetrical secondary aliphatic amines. The procedure works with primary alkylamines with linear and phenyl- and alkoxy-functionalized chains and branched-chain amines.

The trihydride azavinylidene derivatives $\mathrm{OsH}_{3}(=\mathrm{N}=$ $\mathrm{CHR})\left(\mathrm{P}^{\mathrm{i}} \mathrm{Pr}_{3}\right)_{2}$ are the common key intermediates of both processes: the hydrogenation of alkyl nitriles to primary imines and the $\mathrm{C}-\mathrm{C}$ rupture of the nitriles. Their formation involves the insertion of the $\mathrm{N}-\mathrm{C}$ triple bond of the substrates into an $\mathrm{Os}-\mathrm{H}$ bond of the unsaturated tetrahydride $\mathrm{OsH}_{4}\left(\mathrm{P}^{\mathrm{i}} \mathrm{Pr}_{3}\right)_{2}$, which is generated by reductive elimination of hydrogen from the hexahydride precursor. Once the trihydride azavinylidene intermediates are formed, the hydrogenation of the nitriles involves a reaction between molecular hydrogen and the azavinylidene ligand to yield the imines and regenerate the unsaturated tetrahydride catalyst. In the absence of molecular hydrogen, the attack of the tetrahydride to the $\mathrm{C}\left(\mathrm{sp}^{2}\right)$ atom of the azavinylidene produces the $\mathrm{C}-\mathrm{C}$ rupture.

In summary, we have discovered the first osmium catalyst for the efficient formation of symmetrical and asymmetrical secondary aliphatic amines, starting from nitriles, under mild conditions. In addition, we have elucidated the mechanism of the reactions involved and have rationalized the $\mathrm{C}-\mathrm{C}$ rupture of alkyl nitriles promoted by the hexahydride $\mathrm{OsH}_{6}\left(\mathrm{P}^{\mathrm{i}} \mathrm{Pr}_{3}\right)_{2}$.

\section{EXPERIMENTAL SECTION}

Complex $\mathrm{OsH}_{6}\left(\mathrm{P}^{\mathrm{i}} \mathrm{Pr}_{3}\right)_{2}$ (1) was prepared according to the published method. ${ }^{28}$ General information and instrumental methods used for characterization, X-ray information, and computational details are given in the Supporting Information. Chemical shifts (in ppm) are referenced to residual solvent peaks $\left({ }^{1} \mathrm{H},{ }^{13} \mathrm{C}\left\{{ }^{1} \mathrm{H}\right\}\right)$ and external $\mathrm{H}_{3} \mathrm{PO}_{4}\left({ }^{31} \mathrm{P}\left\{{ }^{1} \mathrm{H}\right\}\right)$. Coupling constants, $J$ and $N\left(N={ }^{3} J_{\mathrm{H}-\mathrm{P}}+{ }^{5} J_{\mathrm{H}-\mathrm{P}^{\prime}}\right.$ for ${ }^{1} \mathrm{H}$ or ${ }^{1} J_{\mathrm{C}-\mathrm{P}}+{ }^{3} J_{\mathrm{C}-\mathrm{P}^{\prime}}$ for ${ }^{13} \mathrm{C}$ ), are given in hertz.

Catalytic Hydrogenation of Nitriles to Symmetrical Secondary Amines. The respective nitrile $(0.36 \mathrm{mmol})$ and mesitylene as an internal standard $(50 \mu \mathrm{L}, 0.36 \mathrm{mmol})$ were placed in an NMR tube containing a solution of $\mathbf{1}(18.6 \mathrm{mg}, 0.036 \mathrm{mmol})$ in $0.5 \mathrm{~mL}$ of $\mathrm{C}_{7} \mathrm{D}_{8}$. The mixture was checked by ${ }^{1} \mathrm{H}$ NMR and transferred via cannula to a Fisher-Porter bottle $(70 \mathrm{~mL})$. The Ar atmosphere was replaced by $\mathrm{H}_{2}$, and the system was pressurized to 4 bar. The mixture was magnetically stirred and heated at $100{ }^{\circ} \mathrm{C}$, in an oil bath, for $24 \mathrm{~h}$. Then it was cooled to room temperature, depressurized, and checked by ${ }^{1} \mathrm{H}$ NMR. Yields were calculated on the basis of the integration of the characteristic peaks of the amines formed against the internal standard. The results are the average of at least two duplicate runs. After the crude mixture was checked by ${ }^{1} \mathrm{H}$ NMR, $10 \mathrm{~mL}$ of pentane was added over the reaction mixture. With stirring, several drops of concentrated $\mathrm{HCl}(\mathrm{aq})$ were added to the mixture until a white solid appeared. The solid was dissolved in $\mathrm{MeOH}$ and filtered through neutral alumina; the solvent was removed under vacuum, giving the corresponding amine hydrochlorides, which were characterized by ${ }^{1} \mathrm{H}$ and ${ }^{13} \mathrm{C}$ NMR and HR-MS spectroscopy (see the Supporting Information).

Catalytic Hydrogenation of Nitriles to Asymmetrical Secondary Amines. The same procedure described for the hydrogenation of the nitriles to symmetrical secondary amines was followed, except that $0.9 \mathrm{mmol}$ of external amine were also added to the reaction mixture.

Reaction of 1 with Pivalonitrile: Formation of $\mathrm{OsH}_{4}\left\{\kappa^{1}-N\right.$ $\left.\left(\mathrm{N} \equiv \mathrm{C}^{\mathrm{t} B u}\right)\right\}\left(\mathrm{P}^{\mathrm{i}} \mathrm{Pr}_{3}\right)_{2} \quad$ (2) and $\mathrm{OsH}_{3}\left\{=\mathrm{N}=\mathrm{CH}\left({ }^{\mathrm{t}} \mathrm{Bu}\right)\right\}\left(\mathrm{P}^{\mathrm{i}} \mathrm{Pr}_{3}\right)_{2} \quad$ (3). Pivalonitrile $(22 \mu \mathrm{L}, 0.2 \mathrm{mmol})$ was added to a solution of 1 (100 $\mathrm{mg}, 0.2 \mathrm{mmol}$ ) in $2 \mathrm{~mL}$ of toluene. The resulting solution was heated at $130{ }^{\circ} \mathrm{C}$ for $3 \mathrm{~h}$. The crude reaction mixture was concentrated to dryness under reduced pressure, giving an orange oil. The addition of pentane $(2 \mathrm{~mL})$ at $-78{ }^{\circ} \mathrm{C}$ afforded an orange solid, which was washed with further portions of pentane $(2 \times 2 \mathrm{~mL})$ and dried in vacuo. The resulting orange solid was a 35:65 mixture of isomers 2 and 3. Anal. Calcd for $\mathrm{C}_{23} \mathrm{H}_{55} \mathrm{NOsP}_{2}$ : C, 46.21; H, 9.27; N, 2.34 . Found: C, 46.40; H, 9.43; N, 2.49. IR (ATR, $\left.\mathrm{cm}^{-1}\right): \nu(\mathrm{C}-\mathrm{N})$ and $\nu(\mathrm{Os}-\mathrm{H}) 2090(\mathrm{w}), 1978(\mathrm{~m}), 1790(\mathrm{~m})$. Some orange crystals of 3 , suitable for X-ray diffraction analysis, were grown from a solution of the orange solid in pentane at $-30^{\circ} \mathrm{C}$. Spectroscopic data for 2 are as follows. ${ }^{1} \mathrm{H}$ NMR (300.13 MHz, $\left.\mathrm{C}_{7} \mathrm{D}_{8}, 298 \mathrm{~K}\right): \delta 2.03(\mathrm{~m}, 6 \mathrm{H}, \mathrm{CH}$ $\left.{ }^{\mathrm{i}} \mathrm{Pr}\right), 1.32\left(\mathrm{~m}, 36 \mathrm{H}, \mathrm{CH}_{3}{ }^{\mathrm{i}} \mathrm{Pr}\right), 0.89\left(\mathrm{~s}, 9 \mathrm{H}, \mathrm{CH}_{3}{ }^{\mathrm{t}} \mathrm{Bu}\right),-9.98\left(\mathrm{t},{ }^{3} J_{\mathrm{H}-\mathrm{P}}=\right.$ 13.2, 4H, $\left.\mathrm{OsH}_{4}\right) .{ }^{31} \mathrm{P}\left\{{ }^{1} \mathrm{H}\right\}$ NMR $\left(121.4 \mathrm{MHz}, \mathrm{C}_{7} \mathrm{D}_{8}, 298 \mathrm{~K}\right): \delta 43.1$ (s). ${ }^{13} \mathrm{C}\left\{{ }^{1} \mathrm{H}\right\}$ APT NMR $\left(75.48 \mathrm{MHz}, \mathrm{C}_{7} \mathrm{D}_{8}, 298 \mathrm{~K}\right): \delta 129.9(\mathrm{CN}$, inferred from the HMBC $\left({ }^{1} \mathrm{H},{ }^{13} \mathrm{C}\right)$ spectrum), $29.3\left(\mathrm{C}_{\mathrm{q}}{ }^{\mathrm{t}} \mathrm{Bu}\right.$, inferred from the $\mathrm{HMBC}\left({ }^{1} \mathrm{H},{ }^{13} \mathrm{C}\right)$ spectrum, $27.1\left(\mathrm{CH}_{3},{ }^{\mathrm{t}} \mathrm{Bu}\right), 26.8$ (vt, $\mathrm{N}=$ 24.8, CH, $\left.{ }^{\mathrm{i}} \mathrm{Pr}\right), 20.1 .\left(\mathrm{CH}_{3},{ }^{\mathrm{i}} \mathrm{Pr}\right) .{ }^{1} \mathrm{H}$ NMR $\left(300.13 \mathrm{MHz}, \mathrm{C}_{6} \mathrm{D}_{6}, 298\right.$ $\mathrm{K}): \delta 2.05\left(\mathrm{~m}, 6 \mathrm{H}, \mathrm{CH}^{\mathrm{i}} \mathrm{Pr}\right), 1.44\left(\mathrm{~s}, 9 \mathrm{H},{ }^{\mathrm{t}} \mathrm{Bu}\right), 1.38-1.30(\mathrm{~m}, 36 \mathrm{H}$, $\left.\mathrm{CH}_{3}{ }^{\mathrm{i}} \mathrm{Pr}\right),-10.24\left(\mathrm{t},{ }^{3} \mathrm{~J}_{\mathrm{H}-\mathrm{P}}=13.2,4 \mathrm{H}, \mathrm{OsH}_{4}\right)$. Spectroscopic data for 3 are as follows. ${ }^{1} \mathrm{H}$ NMR $\left(300.13 \mathrm{MHz}, \mathrm{C}_{7} \mathrm{D}_{8}, 298 \mathrm{~K}\right): \delta 3.24(\mathrm{~m}$, $1 \mathrm{H}, \mathrm{N}=\mathrm{CH}), 2.04\left(\mathrm{~m}, 6 \mathrm{H}, \mathrm{CH}{ }^{\mathrm{i}} \mathrm{Pr}\right), 1.22\left(\mathrm{~m}, 36 \mathrm{H}, \mathrm{CH}_{3}{ }^{\mathrm{i}} \mathrm{Pr}\right), 1.08(\mathrm{~s}$, $\left.9 \mathrm{H},{ }^{\mathrm{t}} \mathrm{Bu}\right),-9.86\left(\mathrm{t},{ }^{3} J_{\mathrm{H}-\mathrm{P}}=9.5,1 \mathrm{H}, \mathrm{OsH}\right),-11.57(\mathrm{br}, 1 \mathrm{H}, \mathrm{OsH})$, -13.56 (br t, 1H, OsH). ${ }^{31} \mathrm{P}\left\{{ }^{1} \mathrm{H}\right\}$ NMR $\left(121.4 \mathrm{MHz}, \mathrm{C}_{7} \mathrm{D}_{8}, 298 \mathrm{~K}\right): \delta$ $37.3(\mathrm{~s}) .{ }^{13} \mathrm{C}\left\{{ }^{1} \mathrm{H}\right\}$ APT NMR $\left(75.48 \mathrm{MHz}, \mathrm{C}_{7} \mathrm{D}_{8}, 298 \mathrm{~K}\right): \delta 155.9$ $\left(\mathrm{N}=\mathrm{CH}\right.$, inferred from the $\operatorname{HMBC}\left({ }^{1} \mathrm{H},{ }^{13} \mathrm{C}\right)$ spectrum $), 29.3\left(\mathrm{C}_{\mathrm{q}}\right.$ ${ }^{\mathrm{t}} \mathrm{Bu}$ inferred from the HMBC $\left({ }^{1} \mathrm{H},{ }^{13} \mathrm{C}\right)$ spectrum, $28.5\left(\mathrm{CH}_{3}{ }^{\mathrm{t}} \mathrm{Bu}\right)$, 26.9 (vt, $\mathrm{N}=24.1, \mathrm{CH},{ }^{\mathrm{i}} \mathrm{Pr}$ ), 20.4. $\left(\mathrm{CH}_{3}{ }^{\mathrm{i}} \mathrm{Pr}\right) .{ }^{1} \mathrm{H}$ NMR $(300.13 \mathrm{MHz}$, $\left.\mathrm{C}_{6} \mathrm{D}_{6}, 298 \mathrm{~K}\right): \delta 3.17(\mathrm{~m}, 1 \mathrm{H}, \mathrm{N}=\mathrm{CH}), 2.21\left(\mathrm{~m}, 6 \mathrm{H}, \mathrm{CH}{ }^{\mathrm{i}} \mathrm{Pr}\right), 1.38-$ $1.30\left(\mathrm{~m}, 36 \mathrm{H}, \mathrm{CH}_{3}{ }^{\mathrm{i}} \mathrm{Pr}\right), 1.12\left(\mathrm{~s}, 9 \mathrm{H},{ }^{\mathrm{t}} \mathrm{Bu}\right),-10.00(\mathrm{br}, 1 \mathrm{H}, \mathrm{OsH})$, $-11.85(\mathrm{~s}, 1 \mathrm{H}, \mathrm{OsH}),-13.59\left(\mathrm{td},{ }^{3} J_{\mathrm{H}-\mathrm{P}}=14.5,{ }^{4} J_{\mathrm{H}-\mathrm{H}}=6.1,1 \mathrm{H}\right.$, $\mathrm{OsH})$.

Reaction of 1 with 2-Methoxyacetonitrile: Formation of $\mathrm{OsH}_{3}\left(=\mathrm{N}=\mathrm{CHCH}_{2} \mathrm{OMe}\right)\left(\mathrm{PPr}_{3}\right)_{2}(4),\left(\mathrm{PiPr}_{3}\right)_{2} \mathrm{H}_{4} \mathrm{Os}(\mu-\mathrm{CN}) \mathrm{OsH}_{3}\left\{\kappa^{1-}\right.$ $\mathrm{N}$-(NH=CHCH $\mathrm{NHM}_{2} \mathrm{OM}\left(\mathrm{P}^{\mathrm{i}} \mathrm{Pr}_{3}\right)_{2}$ (5), and $\left(\mathrm{P}^{\prime} \mathrm{Pr}_{3}\right)_{2} \mathrm{H}_{4} \mathrm{Os}(\mu-\mathrm{CN})-$ $\mathrm{OsH}_{3}\left\{\kappa^{1}-\mathrm{N}\right.$ - $\left.\left(\mathrm{NH}_{2} \mathrm{CH}_{2} \mathrm{CH}_{2} \mathrm{OMe}\right)\right\}\left(\mathrm{P}^{\mathrm{i}} \mathrm{Pr}_{3}\right)_{2}(6)$. Two NMR tubes were charged with 2 -methoxyacetonitrile $(4 \mu \mathrm{L}, 0.05 \mathrm{mmol}), 1(25 \mathrm{mg}$, $0.05 \mathrm{mmol}$ ), and $0.5 \mathrm{~mL}$ of toluene- $d_{8}$. One of them was heated to 50 ${ }^{\circ} \mathrm{C}$ and the other to $80{ }^{\circ} \mathrm{C}$. The monitoring of these reactions by ${ }^{1} \mathrm{H}$ and ${ }^{31} \mathrm{P}\left\{{ }^{1} \mathrm{H}\right\}$ NMR (Figures S71-S74) showed the formation of complexes 4-6.

Isolation of $\mathrm{OsH}_{3}\left(=\mathrm{N}=\mathrm{CHCH}_{2} \mathrm{OMe}\right)\left(\mathrm{P}^{\mathrm{i}} \mathrm{Pr}_{3}\right)_{2}$ (4). Method a. 2Methoxyacetonitrile $(15 \mu \mathrm{L}, 0.2 \mathrm{mmol})$ was added to a solution of $\mathbf{1}$ ( $100 \mathrm{mg}, 0.2 \mathrm{mmol}$ ) in $2 \mathrm{~mL}$ of toluene. The resulting solution was heated to $50{ }^{\circ} \mathrm{C}$ for $25 \mathrm{~h}$, and then it was concentrated to dryness under reduced pressure, giving a yellow oil that was washed with further portions of pentane $(2 \times 2 \mathrm{~mL})$ and vacuum-dried. Yield: 20 $\mathrm{mg}(17 \%)$.

Method b. 2-Methoxyacetonitrile $(150 \mu \mathrm{L}, 2.0 \mathrm{mmol})$ was added to a solution of $1(100 \mathrm{mg}, 0.2 \mathrm{mmol})$ in $2 \mathrm{~mL}$ of toluene. The resulting solution was heated at $80{ }^{\circ} \mathrm{C}$ for $30 \mathrm{~min}$, and then it was 
concentrated to dryness under reduced pressure, giving a yellow oil that was washed with further portions of pentane $(2 \times 2 \mathrm{~mL})$ and vacuum-dried. Yield: $23 \mathrm{mg}$ (19\%). HR-MS (electrospray): $m / z$ calcd for $\mathrm{C}_{21} \mathrm{H}_{51} \mathrm{NOOsP}_{2}[\mathrm{M}]^{+}$587.3056; found 587.3152. ${ }^{1} \mathrm{H}$ NMR $\left(300.13 \mathrm{MHz}, \mathrm{C}_{7} \mathrm{D}_{8}, 298 \mathrm{~K}\right): \delta 4.39\left(\mathrm{~m}, 2 \mathrm{H}, \mathrm{OCH}_{2}\right), 3.90(\mathrm{br}, 1 \mathrm{H}$, $\mathrm{N}=\mathrm{CH}), 3.21\left(\mathrm{~s}, 3 \mathrm{H}, \mathrm{OCH}_{3}\right), 1.98\left(\mathrm{~m}, 6 \mathrm{H}, \mathrm{CH}{ }^{\mathrm{i}} \mathrm{Pr}\right), 1.20$ (dvt, $\left.{ }^{3} J_{\mathrm{H}-\mathrm{H}}=6.8, \mathrm{~N}=13.1,36 \mathrm{H}, \mathrm{CH}_{3}{ }^{\mathrm{i}} \mathrm{Pr}\right),-11.23(\mathrm{br}, 1 \mathrm{H}, \mathrm{OsH}),-11.57$ (br, $1 \mathrm{H}, \mathrm{OsH}),-11.66$ (br t, $\left.{ }^{3} \mathrm{~J}_{\mathrm{H}-\mathrm{P}}=12.7,1 \mathrm{H}, \mathrm{OsH}\right) .{ }^{31} \mathrm{P}\left\{{ }^{1} \mathrm{H}\right\}$ NMR (121.4 MHz, $\left.\mathrm{C}_{7} \mathrm{D}_{8}, 298 \mathrm{~K}\right): \delta 38.2(\mathrm{~s}) .{ }^{13} \mathrm{C}\left\{{ }^{1} \mathrm{H}\right\}$ APT NMR $(75.48$ $\left.\mathrm{MHz}, \mathrm{C}_{7} \mathrm{D}_{8}, 298 \mathrm{~K}\right): \delta 145.2\left(\mathrm{t},{ }^{3} J_{\mathrm{C}-\mathrm{P}}=3.8, \mathrm{~N}=\mathrm{CH}\right), 69.0(\mathrm{~s}$, $\left.\mathrm{OCH}_{2}\right), 57.7\left(\mathrm{~s}, \mathrm{OCH}_{3}\right), 26.3$ (vt, $\left.\mathrm{N}=25.0, \mathrm{CH}{ }^{\mathrm{i}} \mathrm{Pr}\right), 20.1\left(\mathrm{~s}, \mathrm{CH}_{3}\right.$ $\left.{ }^{\mathrm{i}} \mathrm{Pr}\right)$.

Identification of $\left(\mathrm{P}^{\mathrm{i}} \mathrm{Pr}_{3}\right)_{2} \mathrm{H}_{4} \mathrm{Os}(\mu-\mathrm{CN}) \mathrm{OsH}_{3}\left\{\kappa^{1} N-(\mathrm{NH}=\right.$ $\left.\left.\mathrm{CHCH}_{2} \mathrm{OMe}\right)\right\}\left(\mathrm{PiPr}_{3}\right)_{2}$ (5). Methoxyacetonitrile $(15 \mu \mathrm{L}, 0.2 \mathrm{mmol})$ was added to a solution of 1 (100 $\mathrm{mg}, 0.2 \mathrm{mmol})$ in $3 \mathrm{~mL}$ of toluene$d_{8}$. The resulting solution was heated to $50{ }^{\circ} \mathrm{C}$ for $44 \mathrm{~h}$. After this time, the ${ }^{1} \mathrm{H}$ and ${ }^{31} \mathrm{P}\left\{{ }^{1} \mathrm{H}\right\}$ NMR spectra of the reaction crude showed a mixture of 4 and 5 in a 5.7:1.0 molar ratio. Selected spectroscopic data for 5 are as follows. ${ }^{1} \mathrm{H}$ NMR $\left(300.13 \mathrm{MHz}, \mathrm{C}_{7} \mathrm{D}_{8}, 298 \mathrm{~K}\right): \delta$ $10.62\left(\mathrm{~d},{ }^{3} J_{\mathrm{H}-\mathrm{H}}=22.3,1 \mathrm{H}, \mathrm{NH}=\mathrm{CH}\right), 7.84\left(\mathrm{br} \mathrm{d},{ }^{3} J_{\mathrm{H}-\mathrm{H}}=22.3,1 \mathrm{H}\right.$, $\mathrm{NH}=\mathrm{CH}), 2.08\left(\mathrm{~m}, 12 \mathrm{H}, \mathrm{CH}^{\mathrm{i}} \mathrm{Pr}\right), 1.43\left(\mathrm{dvt},{ }^{3} \mathrm{~J}_{\mathrm{H}-\mathrm{H}}=5.2, \mathrm{~N}=12.1\right.$, $\left.36 \mathrm{H}, \mathrm{CH}_{3}{ }^{\mathrm{i}} \mathrm{Pr}\right),-10.37\left(\mathrm{t},{ }^{3} \mathrm{~J}_{\mathrm{H}-\mathrm{P}}=14.7,4 \mathrm{H}, \mathrm{OsH}_{4}\right),-11.78\left(\mathrm{t},{ }^{3} J_{\mathrm{H}-\mathrm{P}}\right.$ $\left.=12.8,3 \mathrm{H}, \mathrm{OsH}_{3}\right) .{ }^{31} \mathrm{P}\left\{{ }^{1} \mathrm{H}\right\} \mathrm{NMR}\left(121.4 \mathrm{MHz}, \mathrm{C}_{7} \mathrm{D}_{8}, 298 \mathrm{~K}\right): \delta 44.3$ $\left(\mathrm{s}, \mathrm{POsH}_{4}\right), 24.5\left(\mathrm{~s}, \mathrm{POsH}_{3}\right)$. A small amount of colorless single crystals of $\mathbf{5}$ suitable for $\mathrm{X}$-ray diffraction analysis were grown from a solution of the mixture in pentane at $-30{ }^{\circ} \mathrm{C}$.

Isolation of $\left(\mathrm{P}^{\mathrm{i} P \mathrm{Pr}_{3}}\right)_{2} \mathrm{H}_{4} \mathrm{Os}(\mu-\mathrm{CN}) \mathrm{OsH}_{3}\left\{\kappa^{1} N-\left(\mathrm{NH}_{2} \mathrm{CH}_{2} \mathrm{CH}_{2} \mathrm{OMe}\right)\right\}$ $\left(\mathrm{PiPr}_{3}\right)_{2}$ (6). 2-Methoxyacetonitrile $(15 \mu \mathrm{L}, 0.2 \mathrm{mmol})$ was added to a solution of $\mathrm{OsH}_{6}\left(\mathrm{P}^{\mathrm{i}} \mathrm{Pr}_{3}\right)_{2}(100 \mathrm{mg}, 0.2 \mathrm{mmol})$ in $3 \mathrm{~mL}$ of toluene. The resulting solution was heated at $80{ }^{\circ} \mathrm{C}$ for $24 \mathrm{~h}$. The crude reaction mixture was concentrated to dryness under reduced pressure, giving a dark orange oil. The addition of pentane $(2 \mathrm{~mL})$ at $-78{ }^{\circ} \mathrm{C}$ afforded a white solid that was washed with further portions of pentane $(2 \times 2 \mathrm{~mL})$ and dried in vacuo. Yield: $43 \mathrm{mg}(38 \%)$. Colorless single crystals suitable for X-ray diffraction analysis were grown from a solution of 6 in pentane at $-30{ }^{\circ} \mathrm{C}$. Anal. Calcd for $\mathrm{C}_{40} \mathrm{H}_{100} \mathrm{~N}_{2} \mathrm{OOs}_{2} \mathrm{P}_{4}$ : C, 42.53; H, 8.92; N, 2.48. Found: C, 42.99; H, 9.28; N, 2.55. IR (ATR, $\left.\mathrm{cm}^{-1}\right): \nu(\mathrm{NH}) 3348(\mathrm{w}), \nu(\mathrm{Os}-\mathrm{H})$ and $\nu(\mathrm{CN}) 2078$ (s), 1826 (s). ${ }^{1} \mathrm{H}$ NMR (300.13 MHz, $\left.\mathrm{C}_{7} \mathrm{D}_{8}, 298 \mathrm{~K}\right): \delta$ $3.20\left(\mathrm{br}, 2 \mathrm{H}, \mathrm{OCH}_{2}\right), 2.88\left(\mathrm{~s}, 3 \mathrm{H}, \mathrm{OCH}_{3}\right), 2.72\left(\mathrm{br}, 2 \mathrm{H}, \mathrm{NCH}_{2}\right)$, $1.99-1.81\left(\mathrm{~m}, 12 \mathrm{H}, \mathrm{CH}{ }^{\mathrm{i}} \mathrm{Pr}\right), 1.24\left(\mathrm{dvt}^{3} \mathrm{~J}_{\mathrm{H}-\mathrm{H}}=6.8, N=12.5,36 \mathrm{H}\right.$, $\left.\mathrm{CH}_{3}{ }^{\mathrm{i}} \mathrm{Pr}\right), 1.04\left(\mathrm{~m}, 36 \mathrm{H}, \mathrm{CH}_{3}{ }^{\mathrm{i}} \mathrm{Pr}\right),-10.56\left(\mathrm{t},{ }^{3} \mathrm{~J}_{\mathrm{H}-\mathrm{P}}=14.7,4 \mathrm{H}\right.$, $\left.\mathrm{OsH}_{4}\right),-12.98\left(\mathrm{t},{ }^{3} \mathrm{~J}_{\mathrm{H}-\mathrm{P}}=13.7,3 \mathrm{H}, \mathrm{OsH}_{3}\right) .{ }^{31} \mathrm{P}\left\{{ }^{1} \mathrm{H}\right\}$ NMR $(121.4$ $\left.\mathrm{MHz}, \mathrm{C}_{7} \mathrm{D}_{8}, 298 \mathrm{~K}\right): \delta 44.4\left(\mathrm{~s}, \mathrm{POsH}_{4}\right), 24.8\left(\mathrm{~s}, \mathrm{POsH}_{3}\right) .{ }^{13} \mathrm{C}\left\{{ }^{1} \mathrm{H}\right\}$ APT NMR (75.48 MHz, $\left.\mathrm{C}_{7} \mathrm{D}_{8}, 298 \mathrm{~K}\right): \delta 73.8\left(\mathrm{~s}, \mathrm{OCH}_{2}\right), 58.1(\mathrm{~s}$, $\mathrm{OCH}_{3}$ ), $51.6\left(\mathrm{~s}, \mathrm{NCH}_{2}\right.$ ), 28.8 (vt, $\mathrm{N}=23.2, \mathrm{CH}{ }^{i} \mathrm{Pr}$ ), 25.8 (vt, $\mathrm{N}=$ 23.0, $\mathrm{CH}^{i} \mathrm{Pr}$ ), 20.7, 20.1 (both s, $\mathrm{CH}_{3}{ }^{i} \mathrm{Pr}$ ). The $\mu$-CN signal was not observed.

Structural Analysis of Complexes 3, 5, and 6. X-ray data were collected for the complexes on a Bruker Smart APEX diffractometer equipped with a normal focus and a $2.4 \mathrm{~kW}$ sealed-tube source (Mo radiation, $\lambda=0.71073 \AA$ ). Data were collected over the complete sphere covering $0.3^{\circ}$ in $\omega$. The hydrogen atoms were observed in the last Fourier maps or calculated and were refined freely or using a restricted riding model. The hydrides were located but were refined with fixed $\mathrm{Os}-\mathrm{H}$ distances (1.59 $\AA$ ). The azavinylidene ligand of complex 3 was observed to be disordered and was refined with two moieties, complementary occupancy factors, and isotropic displacement parameters. The hydrides (also disordered) were refined with a fixed $\mathrm{Os}-\mathrm{H}$ distance using the expected geometry as a template. The crystal of $\mathbf{6}$ is the result of the cocrystallization of $0.75 / 0.25$ of amine (6)/imine (5) complexes. The disordered ligands were refined with complementary occupancy factors. The major component (6) was refined freely with anisotropic thermal parameters. The minor component was refined with restricted geometry and isotropic displacement parameters.

\section{ASSOCIATED CONTENT}

\section{Supporting Information}

The Supporting Information is available free of charge at https://pubs.acs.org/doi/10.1021/acs.organomet.0c00236.

General information, crystallographic data, computational details, NMR and IR spectra and energies of computed structures (PDF)

Cartesian coordinates of calculated structures (XYZ)

\section{Accession Codes}

CCDC 1993553-1993555 contain the supplementary crystallographic data for this paper. These data can be obtained free of charge via www.ccdc.cam.ac.uk/data_request/cif, or by emailing data_request@ccdc.cam.ac.uk, or by contacting The Cambridge Crystallographic Data Centre, 12 Union Road, Cambridge CB2 1EZ, UK; fax: +44 1223336033.

\section{AUTHOR INFORMATION}

\section{Corresponding Author}

Miguel A. Esteruelas - Departamento de Química Inorgánica, Instituto de Síntesis Química y Catálisis Homogénea (ISQCH), Centro de Innovación en Química Avanzada (ORFEO-

CINQA), Universidad de Zaragoza-CSIC, 50009 Zaragoza, Spain; (1) orcid.org/0000-0002-4829-7590;

Email: maester@unizar.es

\section{Authors}

Juan C. Babón - Departamento de Química Inorgánica, Instituto de Síntesis Química y Catálisis Homogénea (ISQCH), Centro de Innovación en Qúmica Avanzada (ORFEOCINQA), Universidad de Zaragoza-CSIC, 50009 Zaragoza, Spain; orcid.org/0000-0001-9815-9383

Ana M. López - Departamento de Química Inorgánica, Instituto de Síntesis Química y Catálisis Homogénea (ISQCH), Centro de Innovación en Qúmica Avanzada (ORFEOCINQA), Universidad de Zaragoza-CSIC, 50009 Zaragoza, Spain; O orcid.org/0000-0001-7183-4975

Enrique Oñate - Departamento de Química Inorgánica, Instituto de Síntesis Química y Catálisis Homogénea (ISQCH), Centro de Innovación en Qúmica Avanzada (ORFEOCINQA), Universidad de Zaragoza-CSIC, 50009 Zaragoza,

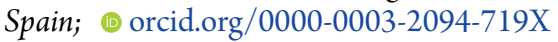

Complete contact information is available at: https://pubs.acs.org/10.1021/acs.organomet.0c00236

\section{Notes}

The authors declare no competing financial interest.

\section{ACKNOWLEDGMENTS}

Financial support from the MINECO of Spain (Projects CTQ2017-82935-P (AEI/FEDER, UE) and RED2018102387-T), Gobierno de Aragón (Group E06_20R and project LMP148_18), FEDER, and the European Social Fund is acknowledged. The BIFI Institute and CESGA Supercomputing Center are acknowledged for technical support and the use of computational resources.

\section{REFERENCES}

(1) Roughley, S. D.; Jordan, A. M. The Medicinal Chemist's Toolbox: An Analysis of Reactions Used in the Pursuit of Drug Candidates. J. Med. Chem. 2011, 54, 3451-3479. 
(2) Taylor, A. R.; Katritzky, R. J. K. In Comprehensive Organic Functional Group Transformations II; Elsevier: Oxford, 2005; pp 255300.

(3) Solomons, G.; Fryhle, C. Organic Chemistry; Wiley: New York, 2000.

(4) Abdel-Magid, A. F.; Mehrman, S. J. A Review on the Use of Sodium Triacetoxyborohydride in the Reductive Amination of Ketones and Aldehydes. Org. Process Res. Dev. 2006, 10, 971-1031.

(5) Trowbridge, A.; Walton, S. M.; Gaunt, M. J. New Strategies for the Transition-Metal Catalyzed Synthesis of Aliphatic Amines. Chem. Rev. 2020, 120, 2613-2692.

(6) Werkmeister, S.; Junge, K.; Beller, M. Catalytic Hydrogenation of Carboxylic Acid Esters, Amides, and Nitriles with Homogeneous Catalysts. Org. Process Res. Dev. 2014, 18, 289-302. (b) Bagal, D. B.; Bhanage, B. M. Recent Advances in Transition Metal-Catalyzed Hydrogenation of Nitriles. Adv. Synth. Catal. 2015, 357, 883-900.

(7) (a) Elangovan, S.; Topf, C.; Fischer, S.; Jiao, H.; Spannenberg, A.; Baumann, W.; Ludwig, R.; Junge, K.; Beller, M. Selective Catalytic Hydrogenations of Nitriles, Ketones, and Aldehydes by Well-Defined Manganese Pincer Complexes. J. Am. Chem. Soc. 2016, 138, 88098814. (b) Weber, S.; Veiros, L. F.; Kirchner, K. Old Concepts, New Application - Additive-Free Hydrogenation of Nitriles Catalyzed by an Air Stable Alkyl Mn(I) Complex. Adv. Synth. Catal. 2019, 361, 5412-5420. (c) Garduño, J. A.; García, J. J. Non-Pincer Mn(I) Organometallics for the Selective Catalytic Hydrogenation of Nitriles to Primary Amines. ACS Catal. 2019, 9, 392-401.

(8) Rajesh, K.; Dudle, B.; Blacque, O.; Berke, H. Homogeneous Hydrogenations of Nitriles Catalyzed by Rhenium Complexes. Adv. Synth. Catal. 2011, 353, 1479-1484.

(9) (a) Bornschein, C.; Werkmeister, S.; Wendt, B.; Jiao, H.; Alberico, E.; Baumann, W.; Junge, H.; Junge, K.; Beller, M. Mild and selective hydrogenation of aromatic and aliphatic (di)nitriles with a well-defined iron pincer complex. Nat. Commun. 2014, 5, 4111. (b) Chakraborty, S.; Leitus, G.; Milstein, D. Selective hydrogenation of nitriles to primary amines catalyzed by a novel iron complex. Chem. Commun. 2016, 52, 1812-1815. (c) Lange, S.; Elangovan, S.; Cordes, C.; Spannenberg, A.; Jiao, H.; Junge, H.; Bachmann, S.; Scalone, M.; Topf, C.; Junge, K.; Beller, M. Selective catalytic hydrogenation of nitriles to primary amines using iron pincer complexes. Catal. Sci. Technol. 2016, 6, 4768-4772.

(10) (a) Choi, J.-H.; Prechtl, M. H. G. Tuneable Hydrogenation of Nitriles into Imines or Amines with a Ruthenium Pincer Complex under Mild Conditions. ChemCatChem 2015, 7, 1023-1028. (b) Neumann, J.; Bornschein, C.; Jiao, H.; Junge, K.; Beller, M. Hydrogenation of Aliphatic and Aromatic Nitriles Using a Defined Ruthenium PNP Pincer Catalyst. Eur. J. Org. Chem. 2015, 2015, 5944-5948. (c) Saha, S.; Kaur, M.; Singh, K.; Bera, J. K. Selective hydrogenation of nitriles to secondary amines catalyzed by a pyridylfunctionalized and alkenyl-tethered NHC-Ru(II) complex. J. Organomet. Chem. 2016, 812, 87-94.

(11) (a) Mukherjee, A.; Srimani, D.; Chakraborty, S.; Ben-David, Y.; Milstein, D. Selective Hydrogenation of Nitriles to Primary Amines Catalyzed by a Cobalt Pincer Complex. J. Am. Chem. Soc. 2015, 137, 8888-8891. (b) Tokmic, K.; Jackson, B. J.; Salazar, A.; Woods, T. J.; Fout, A. R. Cobalt-Catalyzed and Lewis Acid-Assisted Nitrile Hydrogenation to Primary Amines: A Combined Effort. J. Am. Chem. Soc. 2017, 139, 13554-13561. (c) Adam, R.; Bheeter, C. B.; Cabrero-Antonino, J. R.; Junge, K.; Jackstell, R.; Beller, M. Selective Hydrogenation of Nitriles to Primary Amines by using a Cobalt Phosphine Catalyst. ChemSusChem 2017, 10, 842-846.

(12) (a) Yoshida, T.; Okano, T.; Otsuka, S. Catalytic Hydrogenation of Nitriles and Dehydrogenation of Amines with the Rhodium(I) Hydrido Compounds $\left[\mathrm{RhH}\left(\mathrm{PPr}_{3}^{\mathrm{i}}\right)_{3}\right]$ and $\left[\mathrm{Rh}_{2} \mathrm{H}_{2}\left(\mu-\mathrm{N}_{2}\right)\{\mathrm{P}-\right.$ (cyclohexyl) $\left.\}_{3}\right\}_{4}$. J. Chem. Soc., Chem. Commun. 1979, 870-871. (b) Sato, Y.; Kayaki, Y.; Ikariya, T. Cationic Iridium and Rhodium Complexes with C-N Chelating Primary Benzylic Amine Ligands as Potent Catalysts for Hydrogenation of Unsaturated Carbon-Nitrogen Bonds. Organometallics 2016, 35, 1257-1264.
(13) Chin, S. C.; Lee, B. Hydrogenation of nitriles with iridiumtriphenylphosphine complexes. Catal. Lett. 1992, 14, 135-140.

(14) Bose, A.; Saha, C. R. Orthometalated Palladium(II) ComplexCatalysed Reduction of Nitroalkanes and Nitriles. J. Mol. Catal. 1989, 49, 271-283.

(15) (a) Reguillo, R.; Grellier, M.; Vautravers, N.; Vendier, L.; SaboEtienne, S. Ruthenium-Catalyzed Hydrogenation of Nitriles: Insights into the Mechanism. J. Am. Chem. Soc. 2010, 132, 7854-7855. (b) Chakraborty, S.; Berke, H. Homogeneous Hydrogenation of Nitriles Catalyzed by Molybdenum and Tungsten Amides. ACS Catal. 2014, 4, 2191-2194. (c) Chakraborty, S.; Milstein, D. Selective Hydrogenation of Nitriles to Secondary Imines Catalyzed by an Iron Pincer Complex. ACS Catal. 2017, 7, 3968-3972. (d) Li, H.; AlDakhil, A.; Lupp, D.; Gholap, S. S.; Lai, Z.; Liang, L.-C.; Huang, K.-W. Cobalt-Catalyzed Selective Hydrogenation of Nitriles to Secondary Imines. Org. Lett. 2018, 20, 6430-6435. (e) Dai, H.; Guan, H. Switching the Selectivity of Cobalt-Catalyzed Hydrogenation of Nitriles. ACS Catal. 2018, 8, 9125-9130.

(16) (a) Kolb, H. C.; Vannieuwenhze, M. S.; Sharpless, K. B. Catalytic Asymmetric Dihydroxylation. Chem. Rev. 1994, 94, 24832547. (b) Heravi, M. M.; Zadsirjan, V.; Esfandyari, M.; Lashaki, T. B. Applications of sharpless asymmetric dihydroxylation in the total synthesis of natural products. Tetrahedron: Asymmetry 2017, 28, 9871043.

(17) (a) Sánchez-Delgado, R. A.; Rosales, M.; Esteruelas, M. A.; Oro, L. A. Homogeneous catalysis by osmium complexes. A review. J. Mol. Catal. A: Chem. 1995, 96, 231-243. (b) Esteruelas, M. A.; Herrero, J.; López, A. M.; Oliván, M. Alkyne-Coupling Reactions Catalyzed by $\mathrm{OsHCl}(\mathrm{CO})\left(\mathrm{P}^{\mathrm{i}} \mathrm{Pr}_{3}\right)_{2}$ in the Presence of Diethylamine. Organometallics 2001, 20, 3202-3205. (c) Castarlenas, R.; Esteruelas, M. A.; Oñate, E. N-heterocyclic Carbene-Osmium Complexes for Olefin Metathesis Reactions. Organometallics 2005, 24, 4343-4346. (d) Esteruelas, M. A.; García-Yebra, C.; Oliván, M.; Oñate, E.; Valencia, M. Osmium-Catalyzed Allylic Alkylation. Organometallics 2008, 27, 4892-4902. (e) Batuecas, M.; Esteruelas, M. A.; GarcíaYebra, C.; Oñate, E. Redox Isomerization of Allylic Alcohols Catalyzed by Osmium and Ruthenium Complexes Containing a Cyclopentadienyl Ligand with a Pendant Amine or Phosphoramidite Group: X-ray Structure of an $\eta^{3}$-1-Hydroxyallyl-Metal-Hydride Intermediate. Organometallics 2010, 29, 2166-2175. (f) VarelaFernández, A.; García-Yebra, C.; Varela, J. A.; Esteruelas, M. A.; Saá, C. Osmium-Catalyzed 7-endo Heterocyclization of Aromatic Alkynols into Benzoxepines. Angew. Chem., Int. Ed. 2010, 49, 4278-4281. (g) Alós, J.; Bolaño, T.; Esteruelas, M. A.; Oliván, M.; Oñate, E.; Valencia, M. POP-Pincer Osmium-Polyhydrides: Head-to-Head $(Z)$ Dimerization of Terminal Alkynes. Inorg. Chem. 2013, 52, 61996213. (h) Wu, L.; Liu, Q.; Spannenberg, A.; Jackstell, R.; Beller, M. Highly regioselective osmium-catalyzed hydroformylation. Chem. Commun. 2015, 51, 3080-3082. (i) Álvarez-Pérez, A.; GonzálezRodríguez, C.; García-Yebra, C.; Varela, J. A.; Oñate, E.; Esteruelas, M. A.; Saá, C. Catalytic Cyclization of $o$-Alkynyl Phenethylamines via Osmacyclopropene Intermediates: Direct Access to Dopaminergic 3Benzazepines. Angew. Chem., Int. Ed. 2015, 54, 13357-13361. (j) Batuecas, M.; Castro-Rodrigo, R.; Esteruelas, M. A.; GarcíaYebra, C.; López, A. M.; Oñate, E. Aromatic Osmacyclopropenefuran Bicycles and Their Relevance for the Metal-Mediated Hydration of Functionalized Allenes. Angew. Chem., Int. Ed. 2016, 55, 1374913753. (k) González-Fernández, R.; Crochet, P.; Cadierno, V.; Menéndez, M. I.; López, R. Phosphinous Acid-Assisted Hydration of Nitriles: Understanding the Controversial Reactivity of Osmium and Ruthenium Catalysts. Chem. - Eur. J. 2017, 23, 15210-15221.

(18) (a) Andriollo, A.; Esteruelas, M. A.; Meyer, U.; Oro, L. A.; Sánchez-Delgado, R. A.; Sola, E.; Valero, C.; Werner, H. Kinetic and Mechanistic Investigation of the Sequential Hydrogenation of Phenylacetylene Catalyzed by $\mathrm{OsHCl}(\mathrm{CO})\left(\mathrm{PR}_{3}\right)_{2}\left[\mathrm{PR}_{3}=\mathrm{PMe}-t-\right.$ $\mathrm{Bu}_{2}$ and $\left.\mathrm{P}-i-\mathrm{Pr}_{3}\right]$. J. Am. Chem. Soc. 1989, 111, 7431-7437. (b) Esteruelas, M. A.; Oro, L. A.; Valero, C. Hydrogenation of Benzylideneacetone Catalyzed by $\mathrm{OsHCl}(\mathrm{CO})\left(\mathrm{PR}_{3}\right)_{2}\left(\mathrm{PR}_{3}=\mathrm{P}-i-\mathrm{Pr}_{3}\right.$, $\left.\mathrm{PMe}-t-\mathrm{Bu}_{2}\right)$ : New Roles of Dihydrogen Complexes in Homogeneous 
Catalytic-Hydrogenation. Organometallics 1992, 11, 3362-3369. (c) Chelucci, G.; Baldino, S.; Baratta, W. Ruthenium and osmium complexes containing 2-(aminomethyl)pyridine (Ampy)-based ligands in catalysis. Coord. Chem. Rev. 2015, 300, 29-85. (d) Chelucci, G.; Baldino, S.; Baratta, W. Recent Advances in Osmium-Catalyzed Hydrogenation and Dehydrogenation Reactions. Acc. Chem. Res. 2015, 48, 363-379.

(19) (a) Esteruelas, M. A.; Honczek, N.; Oliván, M.; Oñate, E.; Valencia, M. Direct Access to POP-Type Osmium(II) and Osmium(IV) Complexes: Osmium a Promising Alternative to Ruthenium for the Synthesis of Imines from Alcohols and Amines. Organometallics 2011, 30, 2468-2471. (b) Spasyuk, D.; Gusev, D. G. Acceptorless Dehydrogenative Coupling of Ethanol and Hydrogenation of Esters and Imines. Organometallics 2012, 31, 5239-5242. (c) Esteruelas, M. A.; Fernández, I.; López, A. M.; Mora, M.; Oñate, E. OsmiumPromoted Dehydrogenation of Amine-Boranes and B-H Bond Activation of the Resulting Amino-Boranes. Organometallics 2014, 33, 1104-1107. (d) Bolaño, T.; Esteruelas, M. A.; Gay, M. P.; Oñate, E.; Pastor, I. M.; Yus, M. An Acyl-NHC Osmium Cooperative System: Coordination of Small Molecules and Heterolytic B-H and O-H Bond Activation. Organometallics 2015, 34, 3902-3908. (e) Spasyuk, D.; Vicent, C.; Gusev, D. G. Chemoselective Hydrogenation of Carbonyl Compounds and Acceptorless Dehydrogenative Coupling of Alcohols. J. Am. Chem. Soc. 2015, 137, 37433746. (f) Chelucci, G. Ruthenium and osmium complexes in C-C bond-forming reactions by borrowing hydrogen catalysis. Coord. Chem. Rev. 2017, 331, 1-36.

(20) Castarlenas, R.; Esteruelas, M. A.; Oñate, E. Preparation, X-ray Structure, and Reactivity of an Osmium-Hydroxo Complex Stabilized by an N-Heterocyclic Carbene Ligand: A Base-Free Catalytic Precursor for Hydrogen Transfer from 2-Propanol to Aldehydes. Organometallics 2008, 27, 3240-3247.

(21) Buil, M. L.; Esteruelas, M. A.; Herrero, J.; Izquierdo, S.; Pastor, I. M.; Yus, M. Osmium Catalyst for the Borrowing Hydrogen Methodology: $\alpha$-Alkylation of Arylacetonitriles and Methyl Ketones. ACS Catal. 2013, 3, 2072-2075.

(22) Buil, M. L.; Cadierno, V.; Esteruelas, M. A.; Gimeno, J.; Herrero, J.; Izquierdo, S.; Oñate, E. Selective Hydration of Nitriles to Amides Promoted by an Os-NHC Catalyst: Formation and X-ray Characterization of $\eta^{2}$-Amidate Intermediates. Organometallics 2012, 31, 6861-6867.

(23) Esteruelas, M. A.; López, A. M.; Mora, M.; Oñate, E. AmmoniaBorane Dehydrogenation Promoted by an Osmium Dihydride Complex: Kinetics and Mechanism. ACS Catal. 2015, 5, 187-191.

(24) (a) Baratta, W.; Bossi, G.; Putignano, E.; Rigo, P. Pincer and Diamine $\mathrm{Ru}$ and Os Diphosphane Complexes as Efficient Catalysts for the Dehydrogenation of Alcohols to Ketones. Chem. - Eur. J. 2011, 17, 3474-3481. (b) Bertoli, M.; Choualeb, A.; Lough, A. J.; Moore, B.; Spasyuk, D.; Gusev, D. G. Osmium and Ruthenium Catalysts for Dehydrogenation of Alcohols. Organometallics 2011, 30, 3479-3482. (c) Buil, M. L.; Esteruelas, M. A.; Gay, M. P.; Gómez-Gallego, M.; Nicasio, A. I.; Oñate, E.; Santiago, A.; Sierra, M. A. Osmium Catalysts for Acceptorless and Base-Free Dehydrogenation of Alcohols and Amines: Unusual Coordination Modes of a BPI Anion. Organometallics 2018, 37, 603-617.

(25) Esteruelas, M. A.; Lezáun, V.; Martínez, A.; Oliván, M.; Oñate, E. Osmium Hydride Acetylacetonate Complexes and Their Application in Acceptorless Dehydrogenative Coupling of Alcohols and Amines and for the Dehydrogenation of Cyclic Amines. Organometallics 2017, 36, 2996-3004.

(26) Esteruelas, M. A.; García-Yebra, C.; Martín, J.; Oñate, E. Dehydrogenation of Formic Acid Promoted by a TrihydrideHydroxo-Osmium(IV) Complex: Kinetics and Mechanism. ACS Catal. 2018, 8, 11314-11323.

(27) Esteruelas, M. A.; López, A. M.; Oliván, M. Polyhydrides of Platinum Group Metals: Nonclassical Interactions and $\sigma$-Bond Activation Reactions. Chem. Rev. 2016, 116, 8770-8847.

(28) Aracama, M.; Esteruelas, M. A.; Lahoz, F. J.; López, J. A.; Meyer, U.; Oro, L. A.; Werner, H. Synthesis, Reactivity, Molecular-
Structure, and Catalytic Activity of the Novel Dichlorodihydridoosmium(IV) Complexes $\mathrm{OsH}_{2} \mathrm{Cl}_{2}\left(\mathrm{PR}_{3}\right)_{2}\left(\mathrm{PR}_{3}=\right.$ $\left.\mathrm{P}-i-\mathrm{Pr}_{3}, \mathrm{PMe}-t-\mathrm{Bu}_{2}\right)$. Inorg. Chem. 1991, 30, 288-293.

(29) (a) Barrio, P.; Castarlenas, R.; Esteruelas, M. A.; Oñate, E. Triple C-H Activation of a Cycloalkyl Ketone Using an OsmiumHexahydride Complex. Organometallics 2001, 20, 2635-2638. (b) Barrio, P.; Esteruelas, M. A.; Oñate, E. Activation of $\mathrm{C}\left(\mathrm{sp}^{2}\right)-\mathrm{H}$ and Reduction of $\mathrm{C}=\mathrm{E}(\mathrm{E}=\mathrm{CH}, \mathrm{N})$ Bonds with an OsmiumHexahydride Complex: Influence of $\mathrm{E}$ on the Behavior of $\mathrm{RCH}=\mathrm{E}-\mathrm{py}$ Substrates. Organometallics 2004, 23, 3627-3639. (c) Baya, M.; Eguillor, B.; Esteruelas, M. A.; Lledós, A.; Oliván, M.; Oñate, E. Coordination and Rupture of Methyl C $\left(\mathrm{sp}^{3}\right)-\mathrm{H}$ Bonds in OsmiumPolyhydride Complexes with $\delta$ Agostic Interaction. Organometallics 2007, 26, 5140-5152. (d) Esteruelas, M. A.; Masamunt, A. B.; Olivan, M.; Oñate, E.; Valencia, M. Aromatic Diosmatricyclic Nitrogen-Containing Compounds. J. Am. Chem. Soc. 2008, 130, 11612-11613. (e) Eguillor, B.; Esteruelas, M. A.; García-Raboso, J.; Oliván, M.; Oñate, E.; Pastor, I. M.; Penafiel, I.; Yus, M. Osmium NHC Complexes from Alcohol-Functionalized Imidazoles and Imidazolium Salts. Organometallics 2011, 30, 1658-1667. (f) Esteruelas, M. A.; García-Raboso, J.; Oliván, M. Reactions of an OsmiumHexahydride Complex with Cytosine, Deoxycytidine, and Cytidine: The Importance of the Minor Tautomers. Inorg. Chem. 2012, 51, 9522-9528. (g) Bolaño, T.; Esteruelas, M. A.; Fernández, I.; Oñate, E.; Palacios, A.; Tsai, J. Y.; Xia, C. J. Osmium(II)-Bis(dihydrogen) Complexes Containing $\mathrm{C}_{\text {ary }}, \mathrm{C}_{\mathrm{NHC}^{-}}$Chelate Ligands: Preparation, Bonding Situation, and Acidity. Organometallics 2015, 34, 778-789. (h) Babón, J. C.; Esteruelas, M. A.; Fernández, I.; López, A. M.; Oñate, E. Evidence for a Bis(Elongated $\sigma$ )-Dihydrideborate Coordinated to Osmium. Inorg. Chem. 2018, 57, 4482-4491.

(30) (a) Casarrubios, L.; Esteruelas, M. A.; Larramona, C.; Muntaner, J. G.; Oliván, M.; Oñate, E.; Sierra, M. A. Chelated Assisted Metal-Mediated N-H Bond Activation of $\beta$-Lactams: Preparation of Irida-, Rhoda-, Osma-, and Ruthenatrinems. Organometallics 2014, 33, 1820-1833. (b) Casarrubios, L.; Esteruelas, M. A.; Larramona, C.; Lledós, A.; Muntaner, J. G.; Oñate, E.; Ortuño, M. A.; Sierra, M. A. Mechanistic Insight into the Facilitation of $\beta$-Lactam Fragmentation through Metal Assistance. Chem. - Eur. J. 2015, 21, 16781-16785. (c) Casarrubios, L.; Esteruelas, M. A.; Larramona, C.; Muntaner, J. G.; Oñate, E.; Sierra, M. A. 2-Azetidinones as Precursors of Pincer Ligands: Preparation, Structure, and Spectroscopic Properties of CC'N-Osmium Complexes. Inorg. Chem. 2015, 54, 1099811006.

(31) (a) Esteruelas, M. A.; García-Raboso, J.; Oliván, M.; Oñate, E. $\mathrm{N}-\mathrm{H}$ and N-C Bond Activation of Pyrimidinic Nucleobases and Nucleosides Promoted by an Osmium Polyhydride. Inorg. Chem. 2012, 51, 5975-5984. (b) Valencia, M.; Merinero, A. D.; LorenzoAparicio, C.; Gómez-Gallego, M.; Sierra, M. A.; Eguillor, B.; Esteruelas, M. A.; Oliván, M.; Oñate, E. Osmium-Promoted $\sigma$-Bond Activation Reactions on Nucleosides. Organometallics 2020, 39, 312323.

(32) (a) Alabau, R. G.; Eguillor, B.; Esler, J.; Esteruelas, M. A.; Oliván, M.; Oñate, E.; Tsai, J.- Y.; Xia, C. CCC-Pincer-NHC Osmium Complexes: New Types of Blue-Green Emissive Neutral Compounds for Organic Light-Emitting Devices (OLEDs). Organometallics 2014, 33, 5582-5596. (b) Alabau, R. G.; Esteruelas, M. A.; Oliván, M.; Oñate, E.; Palacios, A. U.; Tsai, J.-Y.; Xia, C. Osmium(II) Complexes Containing a Dianionic CCCC-Donor Tetradentate Ligand. Organometallics 2016, 35, 3981-3995.

(33) (a) Crespo, O.; Eguillor, B.; Esteruelas, M. A.; Fernández, I.; García-Raboso, J.; Gómez-Gallego, M.; Martín-Ortiz, M.; Oliván, M.; Sierra, M. A. Synthesis and characterisation of [6]-azaosmahelicenes: the first $\mathrm{d}^{4}$-heterometallahelicenes. Chem. Commun. 2012, 48, 53285330. (b) Eguillor, B.; Esteruelas, M. A.; Fernández, I.; GómezGallego, M.; Lledós, A.; Martín-Ortiz, M.; Oliván, M.; Oñate, E.; Sierra, M. A. Azole Assisted C-H Bond Activation Promoted by an Osmium-Polyhydride: Discerning between $\mathrm{N}$ and NH. Organometallics 2015, 34, 1898-1910. (c) Alabau, R. G.; Esteruelas, M. A.; Oliván, M.; Oñate, E. Preparation of Phosphorescent Osmium- 
(IV) Complexes with $\mathrm{N}, \mathrm{N}^{\prime}, \mathrm{C}$-and $\mathrm{C}, \mathrm{N}, \mathrm{C}^{\prime}$-Pincer Ligands. Organometallics 2017, 36, 1848-1859. (d) Castro-Rodrigo, R.; Esteruelas, M. A.; Gómez-Bautista, D.; Lezáun, V.; López, A. M.; Oliván, M.; Oñate, E. Influence of the Bite Angle of Dianionic C, N, C-Pincer Ligands on the Chemical and Photophysical Properties of Iridium(III) and Osmium(IV) Hydride Complexes. Organometallics 2019, 38, 37073718.

(34) Babón, J. C.; Esteruelas, M. A.; Fernández, I.; López, A. M.; Oñate, E. Reduction of Benzonitriles via Osmium-Azavinylidene Intermediates Bearing Nucleophilic and Electrophilic Centers. Inorg. Chem. 2019, 58, 8673-8684.

(35) Babón, J. C.; Esteruelas, M. A.; Fernández, I.; López, A. M.; Oñate, E. Redox-Assisted Osmium-Promoted C-C Bond Activation of Alkylnitriles. Organometallics 2018, 37, 2014-2017.

(36) Müller, T. E.; Hultzsch, K. C.; Yus, M.; Foubelo, F.; Tada, M. Hydroamination: Direct Addition of Amines to Alkenes and Alkynes. Chem. Rev. 2008, 108, 3795-3892.

(37) (a) Gusev, D. G.; Kuhlman, R.; Sini, G.; Eisenstein, O.; Caulton, K. G. Distinct Structures for Ruthenium and Osmium Hydrido Halides: $\mathrm{Os}(\mathrm{H})_{3}\left(\mathrm{P}^{\mathrm{i}} \mathrm{Pr}_{3}\right)_{2}(\mathrm{X}=\mathrm{Cl}, \mathrm{Br}, \mathrm{I})$ Are Nonoctahedral Classical Trihydrides with Exchange Coupling. J. Am. Chem. Soc. 1994, 116, 2685-2686. (b) Kuhlman, R.; Clot, E.; Leforestier, C.; Streib, W. E.; Eisenstein, O.; Caulton, K. G. Quantum Exchange Coupling: A Hypersensitive Indicator of Weak Interactions. J. Am. Chem. Soc. 1997, 119, 10153-10169. (c) Esteruelas, M. A.; GarcíaRaboso, J.; Oliván, M. Preparation of Half-Sandwich Osmium Complexes by Deprotonation of Aromatic and Pro-aromatic Acids with a Hexahydride Brønsted Base. Organometallics 2011, 30, 38443852. (d) Esteruelas, M. A.; Fernández, I.; López, A. M.; Mora, M.; Oñate, E. Preparation, Structure, Bonding, and Preliminary Reactivity of a Six-Coordinate $\mathrm{d}^{4}$ Osmium-Boryl Complex. Organometallics 2012, 31, 4646-4649. (e) Buil, M. L.; Cardo, J. J. F.; Esteruelas, M. A.; Fernández, I.; Oñate, E. An Entry to Stable Mixed PhosphineOsmium-NHC Polyhydrides. Inorg. Chem. 2016, 55, 5062-5070.

(38) (a) Michelin, R. A.; Mozzon, M.; Bertani, R. Reactions of transition metal-coordinated nitriles. Coord. Chem. Rev. 1996, 147, 299-338. (b) Pombeiro, A. J. L.; Kukushkin, V. Y. Reactivity of Coordinated Nitriles. In Comprehensive Coordination Chemistry II, from Biology to Nanotechnology, 1st ed.; Lever, A. B. P., Vol. Ed.; McCleverty, J. A., Meyer, T. J., Eds.; Elsevier: Oxford, 2004; Vol. 1, pp 639-660.

(39) (a) Shin, J. H.; Savage, W.; Murphy, V. J.; Bonanno, J. B.; Churchill, D. G.; Parkin, G. The syntheses, structures and reactivity of bis(tert-butylcyclopentadienyl)molybdenum derivatives: nitrogen alkylation of an $\eta^{2}$-acetonitrile ligand and influence of the chalcogen on the barrier to inversion of chalcogenoether adducts. J. Chem. Soc., Dalton Trans. 2001, 1732-1753. (b) Lis, E. C.; Delafuente, D. A.; Lin, Y.; Mocella, C. J.; Todd, M. A.; Liu, W.; Sabat, M.; Myers, W. H.; Harman, W. D. The Uncommon Reactivity of Dihapto-Coordinated Nitrile, Ketone, and Alkene Ligands When Bound to a Powerful $\pi$ Base. Organometallics 2006, 25, 5051-5058. (c) Jackson, A. B.; Schauer, C. K.; White, P. S.; Templeton, J. L. Tungsten(II) Monocarbonyl Bis(acetylacetonate): A Fourteen-Electron Docking site for $\eta^{2}$ Four-Electron Donor Ligands. J. Am. Chem. Soc. 2007, 129, 10628-10629. (d) Khosla, C.; Jackson, A. B.; White, P. S.; Templeton, J. L. Bis(acetylacetonate) Tungsten(IV) Complexes Containing a $\pi$-Basic Diazoalkane or Oxo Ligand. Organometallics 2012, 31, 987-994. (e) Brendel, M.; Braun, C.; Rominger, F.; Hofmann, P. Bis-NHC Chelate Complexes of Nickel(0) and Platinum(0). Angew. Chem., Int. Ed. 2014, 53, 8741-8745. (f) Green, R. A.; Hartwig, J. F. Nickel-Catalyzed Amination of Aryl Chlorides with Ammonia or Ammonium Salts. Angew. Chem., Int. Ed. 2015, 54, 3768-3772.

(40) (a) Pérez-Carreño, E.; Paoli, P.; Ienco, A.; Mealli, C. Roles of $\pi$ Alkyne, Hydride-Alkynyl, and Vinylidene Metal Species in the Conversion of Alkynes into Vinylidene: New Theoretical Insights. Eur. J. Inorg. Chem. 1999, 1999, 1315-1324. (b) Grotjahn, D. B.; Zeng, X.; Cooksy, A. L. Alkyne-to-Vinylidene Transformation on trans-(Cl) $\mathrm{Rh}$ (phosphine) ${ }_{2}$ : Acceleration by a Heterocyclic Ligand and
Absence of Bimolecular Mechanism. J. Am. Chem. Soc. 2006, 128, 2798-2799. (c) Grotjahn, D. B.; Zeng, X.; Cooksy, A. L.; Kassel, W. S.; DiPasquale, A. G.; Zakharov, L. N.; Rheingold, A. L. Experimental and Computational Study of the Transformation of Terminal Alkynes to Vinylidene Ligands on trans-(Chloro)bis(phosphine)Rh Fragments and Effects of Phosphine Substituents. Organometallics 2007, 26, 3385-3402. (d) De Angelis, F.; Sgamellotti, A.; Re, N. Full Quantum Mechanical Investigation of the Unimolecular versus Bimolecular Acetylene to Vinylidene Rearrangement in the Prototype trans-Cl$\mathrm{Rh}\left(\mathrm{P}^{\mathrm{i}} \mathrm{Pr}_{3}\right)_{2}$ complex. Organometallics 2007, 26, 5285-5288. (e) Cowley, M. J.; Lynam, J. M.; Slattery, J. M. A mechanistic study into the interconversion of rhodium alkyne, alkynyl hydride and vinylidene complexes. Dalton Trans. 2008, 4552-4554. (f) Vastine, B. A.; Hall, M. B. Density Functional Theory Investigation into the Mechanism for $\eta^{2}$-Alkyne to Vinylidene Isomerization by the Addition of Phenylacetylene to $\left[\left(\eta^{3}-\mathrm{C}_{3} \mathrm{H}_{5}\right) \mathrm{Rh}\left(\mathrm{PiPr}_{3}\right)_{2}\right]$. Organometallics 2008, 27, 4325-4333. (g) Buil, M. L.; Esteruelas, M. A.; Garcés, K.; Oñate, E. From Tetrahydroborate- to Aminoborylvinylidene-Osmium Complexes via Alkynyl-Aminoboryl Intermediates. J. Am. Chem. Soc. 2011, 133, 2250-2263.

(41) (a) Erker, G.; Frömberg, W.; Atwood, J. L.; Hunter, W. E. Hydrozirconation of Nitriles: Proof of a Linear Heteroallene Structure in (Benzylideneamido)zirconocene Chloride. Angew. Chem., Int. Ed. Engl. 1984, 23, 68-69. (b) Fromberg, W.; Erker, G. Hydrozirconierung von nitrilen: Die bildung ein- und zweikerniger (alkylidenamido)zirconocen-komplexe. J. Organomet. Chem. 1985, 280, 343-354. (c) Jordan, R. F.; Bajgur, C. S.; Dasher, W. E.; Rheingold, A. L. Hydrogenation of Cationic Dicyclopentadienyl Zirconium(IV) Alkyl Complexes. Characterization of Cationic Zirconium(IV) Hydrides. Organometallics 1987, 6, 1041-1051. (d) Roskamp, E. J.; Pedersen, S. F. Convenient Routes to Vicinal Diamines. Coupling of Nitriles or N-(Trimethylsilyl)Imines Promoted by $\mathrm{NbCl}_{4}(\mathrm{THF})_{2}$. J. Am. Chem. Soc. 1987, 109, 3152-3154. (e) Debad, J. D.; Legzdins, P.; Batchelor, R. J.; Einstein, F. W. B. New Synthetic Methodology Leading to 16-Electron Asymmetric Complexes of Tungsten: $\mathrm{Cp} * \mathrm{~W}(\mathrm{NO})\left(\mathrm{CH}_{2} \mathrm{SiMe}_{3}\right) \mathrm{R}(\mathrm{R}=$ Alkyl or Aryl $)$. Organometallics 1992, 11, 6-8. (f) Debad, J. D.; Legzdins, P.; Lumb, S. A. Generation and Reactivity of $\mathrm{Cp} * \mathrm{~W}(\mathrm{NO})\left(\mathrm{CH}_{2} \mathrm{SiMe}_{3}\right) \mathrm{H}$, a 16Valence-Electron Alkyl Hydride Complex. Organometallics 1995, 14, 2543-2555. (g) Figueroa, J. S.; Cummins, C. C. The NiobaziridineHydride Functional Group: Synthesis and Divergent Reactivity. J. Am. Chem. Soc. 2003, 125, 4020-4021. (h) Temprado, M.; McDonough, J. E.; Mendiratta, A.; Tsai, Y.-C.; Fortman, G. C.; Cummins, C. C.; Rybak-Akimova, E. V.; Hoff, C. D. Thermodynamic and Kinetic Studies of $\mathrm{H}$ Atom Transfer from $\mathrm{HMo}(\mathrm{CO})_{3}\left(\eta^{5}-\mathrm{C}_{5} \mathrm{H}_{5}\right)$ to $\mathrm{Mo}(\mathrm{N}[t-$ $\mathrm{Bu}] \mathrm{Ar})_{3}$ and $(\mathrm{PhCN}) \mathrm{Mo}(\mathrm{N}[\mathrm{t}-\mathrm{Bu}] \mathrm{Ar})_{3}$ : Direct Insertion of Benzonitrile into the $\mathrm{Mo}-\mathrm{H}$ Bond of $\mathrm{HMo}(\mathrm{N}[\mathrm{t}-\mathrm{Bu}] \mathrm{Ar})_{3}$ forming $(\mathrm{Ph}(\mathrm{H})$ $\mathrm{C}=\mathrm{N}) \mathrm{Mo}(\mathrm{N}[\mathrm{t}-\mathrm{Bu}] \mathrm{Ar})_{3}$. Inorg. Chem. 2008, 47, 9380-9389. (i) Khalimon, A. Y.; Farha, P.; Kuzmina, L. G.; Nikonov, G. I. Catalytic hydroboration by an imido-hydrido complex of $\mathrm{Mo}(\mathrm{IV})$. Chem. Commun. 2012, 48, 455-457.

(42) Calculated Gibbs energies are likely biased by entropy overestimation issues. See: (a) Cooper, J.; Ziegler, T. A Density Functional Study of $\mathrm{S}_{\mathrm{N}} 2$ Substitution at Square-Planar Platinum(II) Complexes. Inorg. Chem. 2002, 41, 6614. (b) Di Tommaso, S.; Tognetti, V.; Sicilia, E.; Adamo, C.; Russo, N. Computational Study of Alkynes Insertion into Metal-Hydride Bonds Catalyzed by Bimetallic Complexes. Inorg. Chem. 2010, 49, 9875-9883. 